\title{
CREDIT ADMUNISTRATION AND WAGE EARNER BANKRUPTCIES
}

\author{
WESLEY A. STURGES $\dagger$ AND DON E. COOPER $\dagger \dagger$
}

BANKRUPTCIES, more than ever and bigger than ever, have followed our credit administration of the past decade. In 1921 our total technical bankrupts were officially reported at 15,200.1 In 1931, this number reached $60,322 . .^{2}$ Outstanding in this history are wage and salary earners. ${ }^{3}$ In numbers, wage and salary earner bankruptcies increased from 5,928 in 1921 to 29,814 in 1931. ${ }^{*}$ Whereas they constituted 39 per cent of the total of our bankrupts in 1921, that ratio had increased to 49 per cent in 1931. In other words, in 1931 almost one-half of our technical bankrupts were wage and salary earners. Furthermore, there is evidence to support the conclusion that a greater percentage of "no-assets" estates is found in our wage and salary earners' bankruptcies than in any other class of bankrupts. Thus, the bankruptcy records for the fiscal year 1930 have been analyzed to show that 84.90 per cent of the estates of wage and salary earners in bankruptcy had no assets and that 98.17 per cent of those estates had assets per estate of less than $\$ 500$ in value. ${ }^{.}$It may also be observed that all but a small fraction of our wage and salary earner bankruptcies are instituted by a voluntary petition. In 1921, there were 31 involuntary petitions among the 5,928 wage and salary

it Lines Professor of Law, Yale University. See the author's Cases on CredrT Transactions (1930) and Cases on Administration of Debtors' Estates (1933).

TitResearch Assistant in the Yale School of Law.

1. REP. ATT'Y GEN. (1921). These reports are for the fiscal year of the Federal Government which ends June 30th.

2. Id. (1931).

3. For the purposes of this paper consideration is given primarily to the implications of wage and salary earner bankruptcies. It should be remarked, however, that the general theme of the article and the legislation herein advocated to aid in consumer credit management are considered as also applicable, to a large extent, to commercial credit management generally, including farm credit.

4. Supra notes 1 and 2.

5. Strengthening of Procedure in the Judicial System, Sen. Doc. No. 65, 72d Congress, 1st Session, 1932, including Report to the President on the Bankruptcy Act and its Administration in the Courts of the United States. The following analysis is set out on page 7:

[487] 
earner bankruptcies; 5,897 were voluntary petitions. 5 In 1931 there. were 116 involuntary petitions among the 29,814 wage and salary earner bankruptcies. ${ }^{7}$ In common with all bankruptcies, discharges are freely granted: "98 per cent of the mercantile bankrupts and about $991 / 2$ per cent of the non-mercantile bankrupts who seek discharges are granted them outright." 8 These percentages have been "practically constant since the earliest days of the act [Bankruptcy Act, 1898] despite the gradual addition of new grounds for denying a discharge." 9

Information upon the net loss to creditors of wage and salary earner bankrupts is not very adequate. There is, however, basis for the statement that the aggregate of the debts per wage or salary earner bankrupt is not as great as in the other classes of bankrupts. "An analysis of the wage-earner bankruptcies closed in the fiscal year 1930 in the 10 districts having the largest number of these bankruptcies revealed that at least 12 per cent of these wage-earners had debts of under $\$ 250$; that at least 12 per cent had debts of from $\$ 250$. to $\$ 500$; and that at least 25 per cent had debts of from $\$ 500$ to. $\$ 1,000$. Thus, in about half the cases (and for the reasons stated in the statistical analysis at page 197 the proportion is probably higher) the debts were $\$ 1,000$ or less. In at least another 24 per cent of the cases the debts were from $\$ 1,000$ to $\$ 2,000$; so that, all told, nearly three-fourths of these bankrupts owed from $\$ 2,000$ on down." 10

Naturally enough, and properly so, commercial, credit and financial interests have manifested general alarm at this rising tide of bankruptcies and credit losses. Why, they question, may debtors so freely legally repudiate their obligations? Answer: Because the Bankruptcy Act so provides. Then, it is replied, the Act must be amended and the sanctity of contract restored.

\footnotetext{
Noncommercial bankruptcies, per cent of cases within ench asset group.

\begin{tabular}{|c|c|c|c|c|c|c|}
\hline $\begin{array}{c}\text { Fiscal year } \\
1980\end{array}$ & $\begin{array}{l}\text { No } \\
\text { assets }\end{array}$ & $\begin{array}{l}\$ 1 \text { to } \\
\$ 100\end{array}$ & $\begin{array}{c}\$ 101 \text { to } \\
\$ 250\end{array}$ & $\begin{array}{c}\$ 250 \text { to } \\
\$ 500\end{array}$ & $\begin{array}{l}\text { Total less } \\
\text { than } \$ 500\end{array}$ & $\begin{array}{l}\text { Total number } \\
\text { of cascs } \\
\text { occupationally }\end{array}$ \\
\hline Wage earners & 84.90 & 9.46 & 2.70 & 1.11 & 98.17 & 27,929 \\
\hline $\begin{array}{l}\text { Farmers ... } \\
\text { Professional }\end{array}$ & 66.73 & 6.79 & 4.85 & 3.48 & 1.86 & 4,371 \\
\hline men $\ldots \ldots$ & 66.32 & 12.86 & 5.38 & 3.66 & 88.22 & 1,283 \\
\hline Others $\ldots \ldots$ & 67.84 & 7.87 & 5.00 & 4.02 & 84.73 & 10,400 \\
\hline
\end{tabular}

*Dismissed cases are excluded.
6. Supra note 1.
7. Supra note 2.
8. Op. cit. supra note 5 , at 12. .
9. Ibid.
10. Id. at $82,197$. 
To meet the demand to save the foundations of our credit structure from this menacing, ever-rising tide of bankruptcies, extensive amendments to the Bankruptcy Act have been recommended to Congress by the Attorney General of the United States.11 These amendments, at least for the most part, are sponsored by substantial commercial, credit and financial interests of the country. ${ }^{12}$

\section{Some Proposed Amendments to the Banloruptcy Act}

What do our commercial, credit and financial interests demand in the premises? What do they consider feasible to be done to the Bankruptcy Act and its administration, in order adequately to deal with our wage and salary earner bankrupts? What is the Executive Department of the United States Government prepared to approve and recommend to Congress with respect to our wage and salary earner bankrupts?

Before reviewing the proposed amendments which most directly relate to wage and salary earner bankrupts, certain proposed amendments of more general application may be briefly noticed. These amendments are, for the most part, predicated upon the conclusion that creditors' coöperation in bankruptcy proceedings under the present law is almost non-existent. ${ }^{13}$ Creditors do not attend creditors' meetings provided for in the Act; they will not concern themselves to determine the election of the trustee for the estate; they will not concern themselves to investigate the history of the bankrupts activities, even the immediate antecedents of his bankruptcy; they are not inclined to attempt to investigate the existence or disposition of assets, or to discover whether or not assets have been disposed of wrongfully as to them. Neither do they appear to challenge the granting of the bankuupt's application for discharge. In short, generally speaking, all that creditors are inclined to do about their bankrupt's estate is to wish that they may receive a check for their claims. From experience and very real tradition, they realize that, under existing administration at least, probably they will receive no check, or at the most, scarcely enough to pay the cost of filing a claim-and why should good money be spent upon a dead horse? ${ }^{14}$

11. Supra note 5; Senate Bill No. 3866, 72d Congress, 1st Session, 1932.

12. Op. cit. supra note 5 , at $43-49$.

13. Id. at 14 et seq; DONOtAN, ADMINISTRATYoN OF BANKRUPT Estates (House Committee Print, 71st Congress, 3d Session, 1931) 4, 5, 13, 22.

14. "Mr. Garrison. Let me give you the figures on the dividends paid to general creditors only.

"Senator Hastings. That is after the expense.

"Mr. Garrison. Yes.

"In 1923 they were a little over 7/2 per cent., and beginning with 1923, running down to 1931, there was a tendency toward a decrease of that, so that by 
These amendments attempt to substitute administrative for creditor control, as follows: (1) Salaried officials, to be known as Examiners, are to be appointed under civil service regulations to function in aid of the referees. They shall examine the debtor or bankrupt and his affairs with a view to discovering assets and whether or not there are causes to deny or to suspend his discharge. Their findings shall be reported to the referee for his consideration. "In those cases in which the bankrupt's failure has been a simple one and an honest one the examination by the examiner would be short and devoted simply to bringing out the facts. If, on the other hand, there were any evidences of irregularity, the examiner would be expected, and would have the means, to make a thorough inquiry. He could conduct examinations under section 21 (a). He could go over the books and records and check them against the statement of aftairs, and so on." 15 (2) Provision is made for the creation and maintenance of a roster of "authorized" trustees in each district who shall be available for election or appointment as trustee of bankrupt estates. This roster shall be made up of applicants who have been investigated for their general qualifications to act as trustees and who have been approved by the court. ${ }^{16}$ (3) Provision is also made for salaried officials who are designated in the proposed amendments as Administrators. There shall be ten of these officials whose duties shall be generally to supervise, in as many districts, the new bankruptcy administration. They shall supervise the actions of the Examiners, investigate applicants for the position of "authorized" trustee and shall report to the court of the district upon general matters concerning administration within the district. ${ }^{17}$ (4) Referees are to be placed upon salary and their powers substantially enlarged-including the important one of passing upon applications for discharge. ${ }^{18}$ Trustees remain upon a fee basis, but their fees shall be computed on the basis of amounts paid to creditors rather than, as now, upon the gross estate. ${ }^{19}$

Whether or not this new Federal, salaried officialdom might accomplish the results anticipated by its proponents it is not proposed

the time you reach the fiscal year 1931, the percentage paid general creditors was 5 per cent. on their claims. It runs on an average for those nine fiscal yeara a little over 6 per cent." Statement of Lloyd K. Garrison, Special Assistant to the Attorney-General, at Hearings before a Sub-Committee of the Committee on the Judiciary, 72d Congress, 1st Session, on Senate Bill No. 3866 (April 12-13, 1932) p. 10.

15. Op. cit. supra note 5 , at 94 et seq.

16. Id. at 107 et seq.

17. Id. at 104 et seq.

18. Id. at 123 et seq.

19. Id. at 111 . 
to discuss. ${ }^{20}$ It may be expected, however, that the "efficiency" of these officials would be measured, primarily, at least, by two consid-

20. In so far as the experience of the Irving Trust Company, as standing Receiver in Bankruptcy for the Southern District of New York, may be regarded as an indication of the feasibility of this proposed organization of bankruptcy officials, the recently released report of the trust company should challenge interest. The following table, which speaks for itself, is taken from the report (page 114) :

ANalysis of Bankruptcy Proceedings Grouped According to Net Rearized Assets, Concluded by Irving Trust Company January 16, 1929 to SEPTEMBER 30, 1932

\begin{tabular}{|c|c|c|c|c|c|c|}
\hline \multirow[b]{2}{*}{ Number } & \multicolumn{2}{|l|}{ oups } & \multirow{2}{*}{$\begin{array}{c}\text { Number } \\
\text { of } \\
\text { Cases }\end{array}$} & \multicolumn{2}{|c|}{$\begin{array}{l}\text { Pcrcentago of } \\
\text { Number of Cascs }\end{array}$} & \multirow{2}{*}{$\begin{array}{c}\text { Net } \\
\text { Amotunt - } \\
\text { Total }\end{array}$} \\
\hline & \multicolumn{2}{|c|}{ Size Limits } & & $\begin{array}{c}{ }^{*} B y \\
\text { Groups }\end{array}$ & Cumulative & \\
\hline 1 & \multicolumn{2}{|c|}{ No Assets } & 73 & $4.34 \%$ & $4.34 \%$ & - \\
\hline 2 & $\$ .01$ to & $\$ 100$ & 444 & $26.43 \%$ & $30.77 \%$ & $\$ 12,898.31$ \\
\hline 3 & 100.01 to & 250 & 136 & $8.10 \%$ & 38. & $23,410.28$ \\
\hline 4 & 250.01 to & 500.00 & 148 & $8.81 \%$ & 47. & $53,058.62$ \\
\hline 5 & 500.01 to & $1,500.00$ & 350 & $20.83 \%$ & 68.51\% & $315,360.74$ \\
\hline 6 & $1,500.01$ to & $5,000.00$ & 318 & $18.93 \%$ & $87.44 \%$ & $850,338.02$ \\
\hline 7 & $5,000.01$ to & $10,000.00$ & 101 & $6.01 \%$ & $93.45 \%$ & $712,471.64$ \\
\hline 8 & $10,000.01$ to & $50,000.00$ & 93 & $5.54 \% 0$ & $98.99 \%$ & $1,908,903.69$ \\
\hline & $50,000.01$ & Up & 17 & $1.01 \%$ & $100 . \%$ & $1,857,481.74$ \\
\hline & TOTAL & & 1680 & $100 . \%$ & & \\
\hline
\end{tabular}

*NOTE-The marked extent to which this experience conforms to the usunl experience may be seen by comparing the percentage of all cases, by groups, shown above, with the figures shown at p. 206 of "The Report of the Attorney General on Bankruptcy Law and Practice," (Senate Document No. 65, 72nd Congress, 1st Session, 1932) where almost identical percentages are given for the same size groups excluding "no asset" cases) as to all cases concluded in the United States in the fiscal year ending June 30, 1930.

\begin{tabular}{|c|c|c|c|c|c|}
\hline \multirow{2}{*}{ Number } & \multirow{2}{*}{$\begin{array}{l}\text { - Realized } \\
\text { Average } \\
\text { Per Cose }\end{array}$} & \multicolumn{2}{|c|}{$\begin{array}{c}\text { Commissions as } \\
\text { Receiver and } \\
\text { Trustee }\end{array}$} & \multicolumn{2}{|c|}{$\begin{array}{l}\text { Unsecurcd Claims } \\
\text { Proved and } \\
\text { Allored }\end{array}$} \\
\hline & & Total & $\begin{array}{l}\text { Average } \\
\text { Per Case }\end{array}$ & Total & $\begin{array}{l}\text { Average } \\
\text { Per Case }\end{array}$ \\
\hline 1 & - & - & - & $\$ 490,074.10$ & $\$ 6,713.34$ \\
\hline 2 & $\$ 29.05$ & $\$ 358.38$ & $\$ 0.81$ & $6,548,521.64$ & $14,748.92$ \\
\hline 3 & 172.13 & $1,437.40$ & 10.57 & $1,715,478.87$ & $12,613.82$ \\
\hline 4 & 364.58 & $4,201.95$ & 28.39 & $1,158,120.67$ & $7,825.14$ \\
\hline 5 & 901.03 & $24,881.55$ & 71.09 & $3,887,053.99$ & $11,105.87$ \\
\hline 6 & $2,674.02$ & $45,956.65$ & 144.25 & $7,205,247.91$ & $22,658.01$ \\
\hline 7 & $7,054.17$ & $25,116.72$ & 248.68 & $3,639,974.36$ & $36,039.35$ \\
\hline 8 & $20,525.84$ & $49,233.88$ & 529.40 & $7,373,445.37$ & $79,284.35$ \\
\hline \multirow[t]{2}{*}{9} & $109,263.63$ & $41,776.69$ & $2,457.45$ & $8,062,150.09$ & $474,244.12$ \\
\hline & $\$ 3,413.50$ & L92,963.22 & $\$ 114.86$ & $\$ 40,080,067.00$ & $\$ 23,857.18$ \\
\hline
\end{tabular}

The percentage of dividends paid to general creditors upon unsecured cloims as proved and allowed in all proceedings concluded by the Trust Company was 
erations: (1) increase of dividends to creditors; (2) decrease of discharges. Such standards would necessarily place a premium upon methods oppressive of debtors and upon technical attacks upon creditors with respect to claims which they sought to prove.

Turning to proposals which relate especially to wage and salary earners, we find that a new section (numbered 75) ${ }^{21}$ is proposed for addition to the Act. Its express purpose is to minimize the pressure of collection proceedings, in aid of a debtor desiring to pay.

A debtor wage earner who is "insolvent or unable to meet his debts as they mature" may petition a bankruptcy court to surrender his non-exempt property, if any he has, for the account of his debts, and to amortize the unpaid balance of his liabilities from future property and, or, earnings. Upon approval of the petition, the court shall order amortization payments "in accordance with his capacity to pay." Such petitioner may extend his amortization over a period of two years and then petition his discharge from such part of his debts as remain unpaid.

If the court is "satisfied that the debtor's petition was in good faith, and that his inability to complete the payments was due to circumstances for which he could not justly be held responsible," he shall be discharged $(75 \mathrm{c})$. A wage earner filing such a voluntary petition to amortize his debts is classified as a "debtor," and not as a "bankrupt." This classification, it is thought, will be inviting to the embarrassed but honest debtor to invoke these proceedings to gain $\mathbf{a}$ moratorium from garnishments or other collection proceedings, and, avoiding the "stigma of bankruptcy," to undertake for the prescribed period of two years to liquidate his obligations from future earnings in so far as he can do so during that period and thereby and therefor receive at the end of the period a discharge unless cause is found to deny it. This procedure would be available to a given debtor wage earner, however, only once in seven years $(75 \mathrm{~d}) .^{22}$

The moratorium, moreover, shall not prevent creditors "whose claims were not provable in the proceedings or arose subsequent to the filing of the petition from pursuing such remedies for the enforcement of their claims against the debtor and such of his property, the title to which has not vested in the trustee, as they would have had if proceedings under this section had not been instituted" (75 e).

8.06 per cent. Report at 22-23. For purposes of comparison with the usual experience in this regard see the statement of Lloyd K. Garrison, supra noto 14.

21. Op. cit. supra note 5 , at 77 et seq.

22. The proposed subsection actually reads as follows: "(d) No potition may be filed under the provisions of this section by a debtor who has within six years previously filed such a petition or been granted a discharge." 
The following question naturally arises in connection with this proposed new section: What is the position of the wage or salary earner if he does not invoke the procedure of the new section? He may become a voluntary bankrupt. The examiner shall investigate his affairs, examine him and submit his findings to the referee who shall have these findings before him in passing upon the banlrupts application for discharge. Elaborate amendments, however, of the discharge section of the present Act will affect him as a voluntary bankrupt. ${ }^{23}$ His application for a discharge may be granted, suspended or denied. Discharge shall be denied, as now, for causes set forth in present section $14 \mathrm{~b}^{24}$ Suspended discharge shall be ordered for a period not exceeding two years from the date of the order, if the court "is satisfied from such evidence as has been adduced (1) that the assets of the bankrupt at the commencement of the proceedings were not of a value equal to 50 cents on the dollar of the amount of his provable debts, unless he satisfies the court that such fact has been due to circumstances for which he can not justly be held responsible; or (2) that he contracted any provable debt within four months prior to the commencement of the proceedings without having at the time of contracting it any reasonable or probable ground of expectation of being able to pay it; or (3) that he has brought on, or contributed to, his bankruptcy by rash and hazardous speculations or by unjustifiable extravagance in living, or by gambling or by culpable neglect of his business affairs" (14 d). During the suspension of a discharge the bankrupt shall be required to turn over his non-exempt property and all such property as is acquired during the suspension, including all income "excepting a reasonable allowance for the living necessities of himself and his dependents" (14 e). Upon the expiration of the suspension period, the court, "if satisfied from the trustee's report and from the reports of the bankrupt submitted by the trustee, and from further examination of the bankrupt as any officer or party in interest may make, that the bankrupt has endeavored in good faith and to the extent of his ability to comply with the terms of the order of suspension, shall grant a discharge. If not so satisfied, after giving him a reasonable opportunity to be heard, the court shall deny the discharge" $(14 \mathrm{e})$. If the discharge is not denied or suspended as herein provided is shall be granted (14 $\mathrm{f}$ ). If a discharge is suspended under this section, the suspension "shall not be deemed to affect the rights of creditors whose claims were not provable in the proceedings or arose

23. Op. cit. supra note 5 , at 96 et seq.

24. Subsection $b$ of present section 14 would be changed but comparatively little. In the proposed amendments it appears as subsection $c$. 
subsequent to the commencement of the proceedings from pursuing such remedies for the enforcement and collection of their claims against the bankrupt and such of his property, the title to which has not vested in the trustee, as they would have had if the discharge had not been suspended" (14 b).

Very briefly summarized, these are the proposals which our commercial, credit and financial interests deem feasible; such are the recommendations of the Executive Department of the United States Government for dealing with our wage and salary earner debtors and bankrupts.

In short, these proposals may be said to have two main purposes, as follows: (1) To assist once in seven years a debtor, insolvent or unable to meet his debts as they mature, for a two-year period to amortize his debts by providing a moratorium against collection remedies of existing creditors having provable claims. If there is an unpaid balance at the end of the two years, the court shall grant a discharge if the court is satisfied that the debtor's petition to amortize was made in good faith, and that his inability to pay in full is due to circumstances for which he could not justly be held responsible. (2) A second main purpose of these proposals is to aid creditors to collect a greater percentage of their claims by more strenuous attempts to discover assets for the bankrupt's estate and to suspend discharges for a period of two years so that future acquired property and income in excess of the bankrupt's living necessities may be appropriated to existing obligations.

\section{Relation of Bankruptcy Administration and Credit Management}

In view of the fact that these proposals relate primarily to proceedings at the time and place of dissolution and liquidation of credit grants-to proceedings at Bankruptcy and the mechanics of bankruptcy administration - no attempt will be made to criticize or to commend them. Whether or not wage and salary earner debtors would be "attracted" or "compelled" to an amortization plan like that contemplated by new section 75 will not be discussed. Whether or not wage and salary earner debtors or bankrupts would be found financially able to amortize any substantial percentage of their debts under the proposed amendments will not be discussed. Probably some would and probably some would not. ${ }^{25}$ Whether or not the Federal courts, with the proposed new officials, should, under guise of their

25. See conclusions by Douglas, based on studies of wage earnor bankrupts in Boston and New Jersey, in Wage Earner Bankruptcies-State vs. Fcderal Control (1933) 42 Y ALE L. J. 591, 626-638. 
Bankruptcy Jurisdiction, be put into this business of collecting small claims, assuming that some should prove collectible under the proposed plan, will not be considered..$^{20}$

In lieu of such considerations, it is proposed to examine the broader economic implications of our wage and salary earner bankruptcies, to question the effectiveness of the Bankruptcy Act or its administration adequately to solve the credit problems implicit in these bankruptcies and to outline remedies seemingly more adequate to deal with those problems.

In approaching these propositions let us first return to the bankruptcy records reported at the beginning of this article to note that there are at least some mitigating factors with respect to the foregoing report of the increasing number of wage and salary earner bankruptcies which deserve mention. The reported increase of these bankrupts may be accounted for to some small degree by the increase in population during the period in question (the national increase being 16.1 per cent from 1920 to 1930), ${ }^{27}$ and by the migration of rural people to and concentration in our industrial centers during at least the greater part of the same period. ${ }^{23}$ Again, as business failures generally have increased during the period in question, so may we conclude that, to some extent, an increasing number of "wage-earners," as officially chronicled in bankruptcy reports, have been former business proprietors who failed in business and went into bankruptey after becoming wage earners because of their debts incurred in conducting a business. ${ }^{29}$ More significant still is the fact of the increase in the number of "business failures," because, in most cases probably, they were "employer failures," and involved displacement of employees. Bradstreet's reports the total "business

26. Those who have warned of the increasing volume of business in the federal courts (see e.g., Frankfurter and Landis, The Busincss of the Supreme Court (1927) 40 HARv. L. REv. 834, 871; (1929) 43 id. 33 ct passim; Franlfurter, Distribution of Judicial Power Between United States and State Courts (1928) 13 ConN. L. Q. 499, 504 et seq.) as well as those who seel: affirmatively to restrict their jurisdiction (see e.g., the Norris Bill to abolish diversity jurisdiction, SEN. REP. No. 691 (1930), commented upon in (1930) 44 Harv. L. REv. 97; Newlin, Proposed Limitations Upoir Our Federal Courts (1929) 15 A.B.A. J. 401 (discussion, not always favorable, of certain proposals to restrict the functions of the federal judiciary)) should be challenged by this feature of the proposed amendments of the Bankruptcy Act. Opposition to this proposed officialdom and to the entire bill has been voiced by Isaac, Should the Federal Government Establish a Banloruptcy Burcau? (1932) 8 NOTRE DAMIE LAWYER 26.

27. U. S. Census Reports, Bureau of the Census (1932).

28. See I REcent SoclaL Trends (1933) 8 et scq.

29. Op. cit. supra note 5, at 197; Douglas, op. cit. supra note 25, at 613. 
failures" for 1931 at 26,381.30 For purposes of interpreting this figure, a "business failure" is defined by Bradstreet's as "suspension of business activity by an individual, firm or corporation in ordinary commercial operation, where there is an actual loss to creditors." Under this classification failure by professional men, such as physicians, lawyers and actors, farmers, independent artisans, housewives and housekeepers, as well as brokers and real estate agents who are not recognized as established firms, is excluded. On the other hand the statistics do include suspension of banks and other strictly financial institutions, even if the suspension prove only temporary." a1 In order to gain an aggregate for 1931 of failures of business proprietorships which probably involved some displacement of employment and loss of wage and salary earnings, we may add to Bradstreet's "business failures" $(26,381)$ the officially reported bankruptcies of farmers $(4,026)^{32}$ and of professional persons $(1,293)^{30}$ for the same year. In short, for the year 1931, it may be concluded that there were approximately 31,700 "employer failures." ${ }^{34} \mathrm{By}$ the same token, there was less than one technically bankrupt wage or salary earner per "employer-failure" in $1931 .^{35}$

These extenuating factors are mentioned that attention may be directed to the proposition that the wage and salary earner bankruptcies are, at least to large extent, symptomatic of more comprehensive problems of economic and credit management than matters of administration of the Bankruptcy Act, and, accordingly, that we may be doubtful from the start if amendment of the Bankruptcy

30. Bradstreet's FaILURe Statistics For 1931 (1932) 6.

31. Id. at 4 .

32. REP. ATr'y GEN. (1931).

33. Ibid.

34. Obviously, some license has been taken in arriving at these respectivo totals for, among other things, the bankruptey records are for the fiscal year 1931, while Bradstreet's are for the calendar year 1931. This, however, would not seem to be very important for present purposes.

35. Of course, it is not intended to imply a diffusion of wage and salary earner bankrupts according to these probable "employer-failures." It is intended merely by these statistics to make plausible what probably most peoplo would believe anyhow, that is, that there is loss of employment and wages which may well be a "contributing factor" in some wage earner bankruptcies. Precise percentages in this connection are not deemed necessary for present purposes.

And of course it must also be recognized that science exacts its toll of unemployment and loss of wages and salary which is much more widely diffused than that resulting from "employer-failures." And of the future, see STUART Ghase, TeCHNocracy, AN Interpretation (1933); Arikight, THe A.,B. C. OF Technocracy (1933); 1 Recent Soclax Trends (1933) xxvii ot scq. and pp. $128,310$. 
Act is an adequate remedy. Clearly, it may be suspected that the proposed bankruptcy reforms promise little in this connection; that commercial, credit and financial interests and the Attorney General are over-simplifying the economic problems implicit in the chronicles of our wage and salary earner bankruptcies by over-consideration of bankruptcy records, the Bankruptcy Act and its administration.

Let us follow this thought into an analysis of the official bankruptcy records, showing, in numbers, the experiences of the several states with bankruptcies during the years 1921-1931.30 At first sight one is impressed with the variations of mathematical totals which appear-variations in one state as compared with another in total number of bankruptcies in a given year, and variations in ratio of wage earner bankruptcies to total bankruptcies in one state as compared with another. It seems impossible, after comparatively examining these varying records, to conclude that they are responsive to any one or more factors which inhere in the Bankruptcy Act or its administration. Instead, one concludes about as follows: That, in so far as Bankruptcy administration is concerned, as long as there are debts and debtors, bankruptcy proceedings and discharges in bankruptcy, there will be bankrupts. That, in so far as Bankruptcy administration is concerned, as long as there are more and more debtors, there may be more and more petitioners in bankruptcy. That even if provisions for discharge were removed from the Bankruptcy Act, there would be more or less "bankrupt" debtors according to the volume and diffusion of credit. That measures, such as amendments of the Bankruptcy Act, designed to minimize the number of technical bankrupts will not check any substantial percentage of our defaulting debtors. Moreover, studies of the bankruptcy records of the several states should not isolate us from matters of general lmowledge, namely, that these records are reports upon only a part of our total debtors and their debts, and that these records reveal not at all the near infinite varieties of circumstances under which debts are incurred or the near infinite variety of changing conditions affecting the several debtors subsequent to the date of incurring their obligations. These unreported facts are, of course, the intervention of the complex fortuities of lifesome of which we know as misfortune, disease, unemployment, extravagance, dishonesty, and which have a most direct impact upon savings, incomes and debts.

With these cautions, we may turn to the more detailed review of the bankruptcy records of the several states. What matters of Bankruptcy reform do they suggest? Looking at a table of the records

36. REPS. ATr'Y GEN. (1921-1931). 
of all the states for the years 1921-1931, the figures for certain states appear distinctive for their size. Those with one thousand or more wage earner bankrupts in 1931 catch the eye. Let us note those states and their records for 1921 and for 1931 as listed below.

\section{TABLE I.}

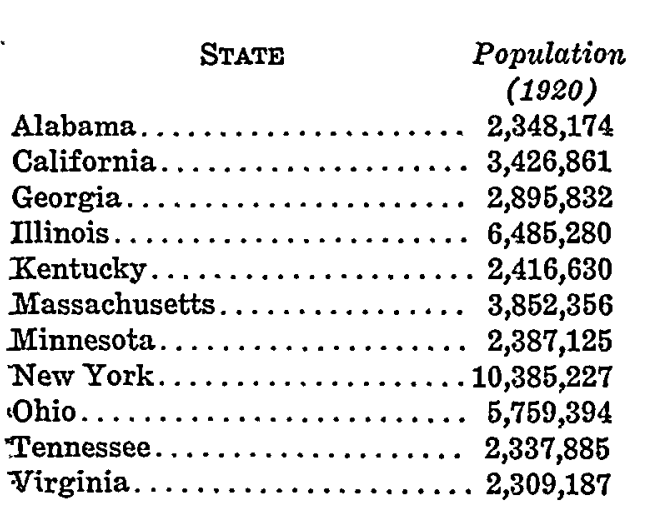

\begin{tabular}{|c|c|c|}
\hline $\begin{array}{c}\text { Total } \\
\text { Bankmeptcies }\end{array}$ & $\begin{array}{c}\text { Wago } \\
\text { Earners }\end{array}$ & $\begin{array}{l}\text { Por } \\
\text { Cont }\end{array}$ \\
\hline 1419 & 1241 & 87.46 \\
\hline 682 & 209 & 30.6 \\
\hline 1063 & 444 & 41.7 \\
\hline 697 & 142 & 20.37 \\
\hline 188 & 66 & 35.2 \\
\hline 728 & 246 & 33.7 \\
\hline 480 & 235 & 48.9 \\
\hline 2039 & 422 & 20.69 \\
\hline 460 & 133 & 28.9 \\
\hline 724 & 525 & 72.5 \\
\hline 516 & 247 & 47.8 \\
\hline
\end{tabular}

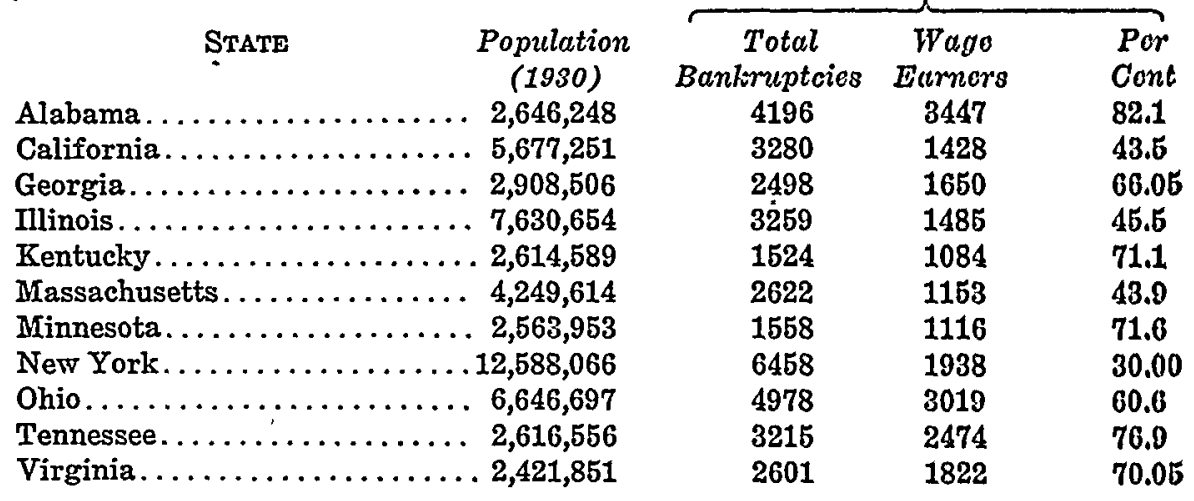

It may be observed that Alabama (with a population in 1930 of $2,646,248)^{37}$ had a greater number of wage earner bankruptcies in 1931 than any other state in the group-greater than Illinois (with a population of $7,630,654$ in 1930), ${ }^{38}$ greater than Massachusetts

37. U. S. Census Reports for 1930. It is interesting to note that porhaps the most impassioned plea made in the hearings upon the amendments to the Bankruptcy Act as proposed by the Attorney-General, opposing the provisions for amortization by wage earners ( $\$ 75$ proposed), and suspension of discharges, was made by Edmund H. Dryer, Esq., of Birmingham, Alabama, and Referee in Bankruptcy for over twenty years. See Part 3, Joint Hearinga Before the Subcommittees of the Committee on the Judicinry on Senate Bill No. 3866 (72d Congress, 1st Session) 617 et seq.

38. U. S. Census Reports for 1930. 
(with a population of 4,249,614 in 1930), ${ }^{39}$ greater than New York (with a population of 12,588,066 in 1930), ${ }^{30}$ greater than Ohio (with a population of 6,646,697 in 1930). 11 Concededly, this fact suggests the existence of varying, highly complex backgrounds of credit, economic, legal and social factors. But what of it for purposes of one or more Bankruptcy reforms?

It may be observed that the wage earner figures for Ohio for 1931 almost equal the total of Massachusetts and New York. But what Bankruptcy reform is suggested by this fact?

In terms of ratio of wage earner bankruptcies to total bankruptcies, Alabama is the only state of the group which had a lower ratio in 1931 than in 1921. But of this observation, as well as those made above, and many other mathematical deductions which might be made from the foregoing table, the question recurs: How do they prompt Bankruptcy reforms?

If we turn to the states having the lowest records for wage earner bankruptcies, selecting, arbitrarily again, those states which did not have in excess of 100 wage earner bankruptcies in 1931, there would be the following table:

TABLE II.

1921

STATE

$$
\begin{gathered}
\text { Population } \\
\text { (1920) }
\end{gathered}
$$

Arizona................. 334,162

Arkansas.................. 1,752,204

Delaware................ 223,003

District of Columbia......... 437,571

Florida................. 968,470

Idaho ................... 431,866

Maryland................ 1,449,661

Nevada.................. 77,407

New Hampshire. . . . . . . . . 4 443,083

New Mexico................ 360,350

North Carolina ............. 2,559,123

North Dakota. . . . . . . . . . . . . 646,872

Rhode Island. . . . . . . . . . . . . 604,397

South Carolina.............. 1,683,724

South Dakota ............. 636,547

Texas................. 4,663,228

\begin{tabular}{|c|c|c|}
\hline $\begin{array}{c}\text { Total } \\
\text { Banziruptcics }\end{array}$ & $\begin{array}{l}\text { Wage } \\
\text { Earnzers }\end{array}$ & $\begin{array}{l}\text { Per } \\
\text { Cent }\end{array}$ \\
\hline 21 & 9 & 42.8 \\
\hline 163 & 31 & 19.01 \\
\hline 20 & 1 & 5.0 \\
\hline 35 & 5 & 14.28 \\
\hline 111 & 2 & 1.8 \\
\hline 80 & 37 & 46.25 \\
\hline 84 & 12 & 14.28 \\
\hline 11 & 4 & 36.36 \\
\hline 53 & 20 & 37.7 \\
\hline 20 & 6 & 30.0 \\
\hline 63 & 1 & 1.68 \\
\hline 146 & 22 & 15.06 \\
\hline 50 & 16 & 31.0 \\
\hline 58 & 3 & 5.17 \\
\hline 76 & 14 & 18.4 \\
\hline 383 & 38 & 9.92 \\
\hline 24 & 7 & 29.17 \\
\hline
\end{tabular}

Wyoming............... 194,402

39. Ibid.
40. Ibid.
41. Ibid. 
1931

\begin{tabular}{|c|c|c|c|c|}
\hline State & $\begin{array}{l}\text { Population } \\
(1980)\end{array}$ & $\begin{array}{c}\text { Total } \\
\text { Bankmeptcies }\end{array}$ & $\begin{array}{c}\text { Wage } \\
\text { Earnors }\end{array}$ & $\begin{array}{l}\text { Por } \\
\text { Cont }\end{array}$ \\
\hline Arizona. & 435,573 & 71 & 24 & 33.8 \\
\hline Arkansas. & $1,854,482$ & 323 & 52 & 16.08 \\
\hline Delaware. & 238,380 & 59 & ธ & 8.47 \\
\hline District of Columbia .......... & 486,869 & 136 & 63 & 46.3 \\
\hline Florida. . & . 1,468,211 & 613 & 31 & 5.05 \\
\hline Idaho..... & - 445,032 & 186 & 52 & 27.0 \\
\hline .............. & . $1,631,526$ & 340 & 39 & 11.47 \\
\hline 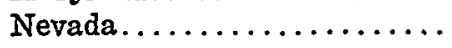 & 91,058 & 52 & 15 & 28.8 \\
\hline New Hampshire.$\ldots \ldots \ldots \ldots$ & 465,293 & 84 & 42 & 50.0 \\
\hline New Mexico.............. & 423,317 & 55 & 18 & 32.7 \\
\hline North Carolina............ & $3,170,276$ & 584 & 18 & 3.08 \\
\hline North Dakota. & 680,845 & 205 & 45 & 21.0 \\
\hline Rhode Island $\ldots \ldots \ldots \ldots \ldots \ldots$ & 687,497 & 200 & 80 & 40.0 \\
\hline South Carolina . . . . . . . . . . & $1,738,765$ & 167 & 10 & 5.08 \\
\hline South Dakota............ & 692,849 & 240 & 61 & 25.4 \\
\hline Texas. . . . . . . . . . . . . . & $5,824,715$ & 929 & 58 & 6.24 \\
\hline (n........... & 225,565 & 58 & 42 & 72.4 \\
\hline
\end{tabular}

What is there in Bankruptcy law or practice to account for the largest (territorially) state and the smallest appearing in this second grouping? What of it, for purposes of Bankruptcy reforms, that, in 1931, each state of the first group had more wage earner bankruptcies than the aggregate of all of the states of the second group?

In terms' of "factors" such as geographical location, personnel of population, balance of urban and rural population, business and commercial pursuits, there seems to be no evidence upon which to conclude that variations in the ever-increasing number of technicul bankruptcies in these several states and in the ratio of wage and salary earner bankruptcies to total bankruptcies point to any particular reforms in the Bankruptcy Law or its administration.

In terms of gross population, concededly the total population of the first group of states listed above, is greater than that of the second group. Concededly, also, population in the first group of states is more highly concentrated in urban and industrial centers than in the second group of states. But what of these differences, however substantial, as a basis upon which to predicate bankruptcy reforms? In so far as Bankruptcy administration is concerned, more debtors, to repeat, may be expected to mean a greater number of bankrupts. In so far as Bankruptcy administration is concerned, more wage and salary earner debtors may be expected to yield more wage and salary earner bankruptcies as wage and salary earner volume of credit is expanded and diffused. On the other hand, amendments of the Bankruptcy Act restricting discharges would restrict bank- 
ruptey discharges, as repeal of the Bankruptcy Act would eliminate technical bankruptcies-but not debtors bankrupt in fact.

Carrying this analysis to a group of contiguous states, let us observe the records of the six New England States, as set forth below.

TABLE III.

\begin{tabular}{|c|c|c|c|c|}
\hline \multirow[b]{2}{*}{ State } & \multirow[b]{2}{*}{$\begin{array}{l}\text { Population } \\
(19 \Omega 0)\end{array}$} & \multicolumn{3}{|c|}{1921} \\
\hline & & $\begin{array}{c}\text { Total } \\
\text { Banleruptcies }\end{array}$ & $\begin{array}{c}\text { Wage } \\
\text { Eariters }\end{array}$ & $\begin{array}{l}\text { Por } \\
\text { Cent }\end{array}$ \\
\hline Maine.... & 768,014 & 420 & 276 & 65.7 \\
\hline Vermont. . & 352,428 & 85 & 49 & 57.6 \\
\hline New Hampshire. & 443,083 & 53 & 20 & 37.7 \\
\hline Mrassachusetts.... & $3,852,356$ & 728 & 240 & 33.7 \\
\hline Rhode Island.... & . $\quad 604,397$ & 50 & 16 & 31.0 \\
\hline \multirow[t]{2}{*}{ Connecticut. . } & $1,380,631$ & 138 & 7 & 5.07 \\
\hline & & \multicolumn{3}{|c|}{1931} \\
\hline State & $\begin{array}{c}\text { Population } \\
(19 s 0)\end{array}$ & $\begin{array}{c}\text { Total } \\
\text { Banliruptcies }\end{array}$ & $\begin{array}{c}\text { Wago } \\
\text { Eamers }\end{array}$ & $\begin{array}{l}P c r \\
\text { Cont }\end{array}$ \\
\hline Maine... & 797,423 & 869 & 609 & 70.08 \\
\hline Vermont. . & 359,611 & 210 & 119 & 56.6 \\
\hline New Hampshire.... & . . 465,293 & 84 & 42 & 50.0 \\
\hline MIassachusetts...... & .. $4,249,614$ & 2622 & 1153 & 43.9 \\
\hline Rhode Island. & 687,497 & 200 & 80 & 40.0 \\
\hline Connecticut. . & $1,606,903$ & 534 & 241 & 45.1 \\
\hline
\end{tabular}

There were fewer wage earner bankruptcies in the whole of $\mathrm{New}$ England in 1931 than in either Alabama, Ohio or Tennessee. Does the Bankruptcy Act, or its administration especially favor New England, or unduly prejudice Alabama, Ohio and Tennessee? What Bankruptcy reforms could be capable of improving wage and salary earner credit in New England? What reforms of the Bankruptcy Act would aid in removing these diversities of bankruptcy totals?

This brief review of some gross totals of bankruptcies, their variations in several states and this questioning as to whether or not the varying totals point to needed Bankruptcy reform is indulged to challenge the popular practice of predicating the necessity of such reform upon the fact that we have a large number of bankruptcies and that their totals for the country are increasing year by year.: For purposes of alarm and focusing attention, this practice of quoting

42. See, for example, Mressage of the President to the Senate and House of Representatives, February 29, 1932; Strengthening of Procedure in the Judicial System, Sen. Doc. No. 65, 72d Congress, 1st Session, at page $\mathrm{xl}_{\text {; }}$ DONOVAN, ADIIINISTRATION OF BANKRUPT ESTATES, op. cit. supta note 13, at 7 . If the present rate of increase should continue the Russel Sage Foundation has estimated that "one out of every 15 wage-earner families in 1910 would bo potentially bankrupt, in the bankruptcy courts, or prevented from bankruptcy by reason of discharge within six years." 
rising totals of bankruptcies with their increasing losses to creditors may well be effective, but it seems unwarranted to conclude that totals in the bankruptcy reports are ruled by factors inherent in the Bankruptcy Act or its administration, or that amendments of the Bankruptcy Act looking to its more "efficient" administration in terms of greater dividends for creditors, provide an effective solution of the credit problems implicit in these bankruptcy records.

There remains, however, to observe one suggestion which frequently recurs as somewhat of an attempt at particularization in connection with quotations of rising bankruptcy totals and the need of bankruptcy reform. Suggestion is made, though somewhat indefinitely, of a correlation of collection remedies, bankruptcies and bankruptcy reforms-as if they had some particularly significant mutual relationship. ${ }^{43}$ It would seem very reasonable to conclude that probably most wage and salary earner bankrupts are driven to voluntary bankruptcy as apparently the only way out of their debt burdens, and, as is probably necessary in many cases, in order to preserve their jobs by responding to their employers' demands that pending garnishments and assignments of wages be cleaned up. In other words, quite probably, most of our wage and salary earners have not gone through Bankruptcy just for the experience, but instead, compelling collection proceedings have at least contributed to the decision to file a petition. But these matters cannot be eliminated by amending the Bankruptcy Act. Collection remedies and such reforms of collection procedures as have been accomplished in the past decade do not explain the ever-increasing number of bankruptcies of that period. This identification of collection remedies as one of the touching-off "factors" of these bankruptcies indicates no reforms of the Bankruptcy Act which promise its better administration. Even less does it indicate a solution of the problems of credit management signalized by these bankruptcies. And while, as is hereafter urged, reform of collection procedures and a coöperative amendment of the Bankruptcy Act may facilitate a solution of these problems, the necessary reforms and amendments are not reflected in an exposition of the impact of collection proceedings upon technical bankrupts. If collection remedies of the several states were entirely eliminated, very probably bankruptcies could be cut down; but such a proposal seems too impracticable further to discuss. And, at all events, the elimination of these remedies could not be accomplished by changes in the Bankruptcy Act or its administration. On the other hand, if there is need for additional collection remedies, as such, to aid the creditors of our wage and salary earners, it is not clear that they can be more adequately provided for by reforms

43. Op. cit. supra note 5 , at 81 . 
of the Bankruptcy Act than by the several states.14 Moreover, quite clear is it that, in the case of wage and salary earners, as distinguished from manufacturers and merchants, for example, their sources and lines of credit are local and therefore, there is little necessity of accommodating out-of-state creditors with the Federal judicial system.

By way of more specific consideration of the relation of collection remedies to and their impact upon wage and salary earner debtors and their bankruptcies, this question may be posed: Do the collection remedies of the several states account for their increasing number of wage and salary earner bankruptcies, or explain or bear upon the statistical variations of the several states in their respective gross totals of bankruptcies and wage and salary earner bankruptcies?

In connection with this question, let us turn first to the New England states with their record of bankruptcies as set forth above in Table III. They will be cited first in this connection because it is believed that the legal collection remedies of those states are most rigorous toward the debtor and that their allowances of wage and salary exemptions are least liberal.

The original writ with which civil actions are commenced in this group of states may be framed so as to include an attachment of the debtor's property, in every case involving a money demand and without the necessity of showing any particular statutory ground

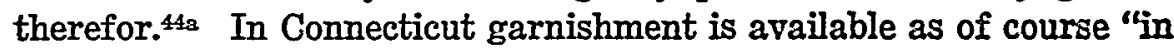
any civil action in which a judgment or decree for the payment of money may be rendered" when "a debt is due from any person to the

44. Of course, under the present Bankruptcy Act, upon the intervention of proceedings thereunder, the usual collection remedies are supplanted by the agencies provided for in the statute. The amortization plan recommended by the Attorney-General, as reviewed above, proposes to extend the operation of these agencies over a two-year period pending a suspended discharge. As the Bankruptcy Act is reformed by extending the time for administration and collections thereunder, there is, of course, possibility that collections will be greater than in a shorter period. But observe that this is a comparison of Bankruptcy collections for one period of administration as compared with such collections for a longer period. It does not point to their superiority over the ordinary collection remedies which would be available if proceedings under the Bankruptcy Act had not intervened. In other words, the longer a debtor is held in Bankruptcy administration and his discharge suspended, theoretically, at least, the greater may be the collections by Bankruptcy officials from him, but this proposition does not warrant the conclusion that more will be sa collected than would be collected during like period by ordinary collection remedies out of Bankruptcy administration.

44a. Conn. Gen. Stat. (1930) § 5712; Mie. Rev. Stat. (1930) c. 95, § 2;

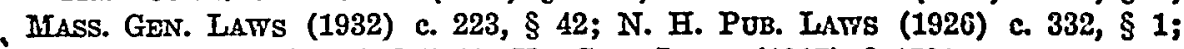
R. I. GEN. LAWS (1923) § 5146; VT. GEN. LaAWS (1917) § 1701. 
defendant;" 45 in Maine and Massachusetts all personal actions except those of detinue, replevin, actions on the case for malicious prosecution, slander or libel, and assault and battery may be commenced by trustee process (garnishment) ; ${ }^{40}$ in New Hampshire any personal action except replevin may be begun in the same manner; ${ }^{47}$ in Rhode Island an original writ commanding the attachment of the personal estate of the defendant in the hands of any third person as trustee may be issued on affidavit of the plaintiff that he has a just claim, that it is due, and that he expects to recover thereon a sum sufficient to give jurisdiction to the court to which such writ is returnable; ${ }^{48}$ and in Vermont all actions founded on contract, express or implied, and actions for an accounting or on a book account may be commenced by trustee process. ${ }^{49}$ And where judgment is rendered against the defendant in the main action, execution may issue agninst any person charged or adjudged as trustee, or against the debts and credits of the defendant which have been attached in this manner. ${ }^{50}$

Wage exemptions ${ }^{51}$ range from $\$ 10$ in Vermont and Rhode Island

45. Conn. Gen. Stat. (1930) §5763. Debts due "at the time of the sorvice of the foreign attachment" shall be disclosed by the garnishee. Id. $\$ 5768$.

46. Me. Rev. Stat. (1930) c. 100, § 1, Mass. Gen. Laws (1932) c. 246, § 1. In Maine, no person shall be adjudged trustee "by reason of any monoy" or other thing due from him to the principal defendant, unless at the time of the service of the writ upon him, it is due absolutely and not on any contingency." ME. REv. STat. (1930) c. 100, § 55. Similarly, in Massachusetts. Mass. Gen. Laws (1932) c. 246, §§ 10, 24.

47. N. H. Pub. Laws (1926) c. $356, \S 1$. Debts which becomo duo up to the time of the trustee's deposition or answer, as well as those which are duo at the time of the service of the writ upon him are bound. Id. c. 356, § 19. And see Gove v. Varrell, 58 N. H. 78 (1877).

48. R. I. GEN. LAWS (1923) § 5146. The trustee is required to rendor an account in writing, on oath, of what estate of the principal defendant, if any, he had at the time the writ was issued. Id. § 5211 .

49. VT. GEN. LAWS (1917) § 1936. "The liability of the person summoned as trustee is determined according to the state of facts at the time of trial; so that funds coming into the trustee's hands after the service of the writ aro held, equally with those coming into his hands before that time." Newoll v. Ferris, 16 Vt. 135 (1844). See also, Northfield Trust Co. v. Cutting, 95 Vt. 343, 115 Atl. 289 (1921).

50. Conn. Gen. Stat. (1930) § 5814; ME. Rev. Stat. (1930) c. 61, § 100; Mass. Gen. Laws (1932) c. 246 , $\S 39-44 ;$ N. H. PUb. LAWS (1926) c. 356, § 33; R. I. GEN. LAWS (1923) § 5255; VT. GEN. LAWS (1917) § 2007.

51. Other exemption provisions, including those for the homestead, personal property, life insurance, and so on, were examined contemporaneously, but in order not unduly to extend this discussion they will not be specially considered. It seems quite clear, however that their inclusion would not havo prejudiced the conclusions here advanced.

52. VT. GeN. LAWS (1917) § 1944; R. I. GeN. LAWS (1923) § 5234. 
to $\$ 20$ in Maine, Massachusetts and New Hampshire. ${ }^{.5}$ In Rhode Island and New Hampshire there are no wage exemptions as to claims for necessaries, and $\$ 10$ only are exempt in Maine and Massachusetts in such cases. ${ }^{54} \$ 15$, except for board and lodging, are exempt in Connecticut. 55

Turning to the states listed under Tables I and II which will be considered together, we find that, in the main, attachment and garnishment are available not as a matter of course, but, expressly at least, ${ }^{56}$ only upon a showing by affidavit of the existence of certain specific statutory grounds and upon the posting of a bond usually in double the amount sought to be recovered ${ }^{\text {st }}$ and conditioned that the plaintiff shall pay all damages and costs which the defendant may sustain in consequence of wrongful issuance. ${ }^{68}$ With respect to attachment these formal grounds may, with the exception of a few

53. ME. REv. STAT. (1930) c. $100, \S 55$ (due for a period not exceeding one month next preceding the service of process); MIASS. GEN. LAWS (1932) c. $246, \S 28 ;$ N. H. PUB. LaWwS (1926) c. $356, \S 20$.

54. Supra note 53.

55. CoNN. GEN Stat. (1930) § 5793 (exception as to rental applies only where it does not exceed \$25).

56. ALA. CODE (1928) §§ 6172-6176; CAI. CODE Crv. Proc. (Deering, 1931) $\S \S 537-539$; GA. CODE ANN. (1926) §§ 5055-5057; InL. REv. STAT. (Smith-Hurd, 1931) c. 11, $\S 1$ et seq; KY. Codes ANN. (Carroll, 1927) Civ. Prac. $\S \S 19 d-$ 198; Minn. Stat. (Mison, 1927) §9343 et. seq; N. Y. C. P. A. \$\$ 902-903, 907; OHIO GeN. Code (Page, 1926) §§ 11819-11821; TENN. CODE (1932) §§ 9396, 9400, 9416, 9418; VA. Code ANN. (1930) §§ 6378-6379, 6384 et seq; ARIz. CodE (Struckmeyer, 1928) §§ 4241-4244; ARK. DIG. STAT. (Crawford \& Hoses, 1919) §§ 494-498; DeL. REv. STAT. (1915) § 4118; D. C. CoDE (1929) tit. 24, § 121 et seq; FLA. CoMP. LAWS (1927) §§ 5255-5259, 5264; IDAHO CODE ANN. (1932) § 6-501-D-502; MD. ANN. CoDE (Bagby, 1924) art. 9, § 1 et. seq; NEv. Coss. LAWS (Hillyer, 1929) §§ 8703-8705; N. MI. STAT. ANN. (Courtright, 1929) $\S \S 105-1601-105-1605 ;$ N. C. CoDE (1931) §§ 798-803; N. D. CoMrP. LnTVS ANN. (1913) §§ 7537-7538, 7543; S. C. CODE OF LeAWS (1932) §§ 527-530, 536, 546; Tex. REv. Crv. CODE (1928) art. 275-279; Wyo. REv. StAT. (1931) § 89-3301 et. seq.

The word "expressly" is used in the text in recognition of the fact that the practice in these states may not uniformly conform to the strict letter of the statutes. For example, if in a particular state it is accepted practice for debtors not to contest alleged grounds of attachment, the net result would be practical nullification of the statutes. But whatever variations in practice may exist in these states, it is not thought that our conclusions would be prejudiced.

57. Variations, of course, exist. For example, in Californin the bond must be in a sum not exceeding the amount claimed in the action; in North Dakots it must be at least, and in Arizona not less than, the amount claimed; in New York it must be at least $\$ 250$.

58. In Alabama, Arizona and Tennessee the bond is further conditioned that the plaintiff shall prosecute the action "with effect." 
anomalies ${ }^{50}$ be reduced to one: the inadequacy of orclinary process, various ramifications of which are minutely particularized and spelled out in the statutes. For example, non-residence of the debtor is uniformly a sufficient ground for attachment, and other circumstances relating to the person of the debtor such as absence from the state for a specified period, absconding, removing or concealing himself to avoid service, frequently recur in the statutes as sufficient cause. ${ }^{60}$ Another grouping of the several situations in which ordinary process is deemed inadequate may be classified as relating to tho liable property of the debtor, all of such grounds being, when allowance is made for the variety of expression found in the statutes, predicated upon the debtor's fraudulent disposition of his property. ${ }_{0} 1$ Garnishment as the mode of attaching debts and credits due the principal defendant, is, as a general proposition, available at the commencement or during the pendenicy of suit under the same circumstances and upon the same conditions as attachment.02 In Ala. bama, Arizona, Arkansas, Florida, Georgia, Minnesota, New Mexico,

59. For example, fraud on the part of the debtor in contracting the dobt or incurring the obligation on which the suit is brought is a ground in Illinois. In California, Idaho, Nevada and Wyoming attachment may issue whore the debt or contract sued upon is unsecured by mortgage, lien or pledge, or if originally so secured, the security has become valueless, or insufficient, without act of the plaintiff. And in New Mexico, an attachment may issue where tho debt was incurred for the necessaries of life.

60. Supra note 56.

61. Such grounds embrace various devices through which the debtor may seek to avoid payment-concealment of his effects; removal of his proporty outside the state or jurisdiction of the court; fraudulent convoyances, transfers and assignments of his property; conversion of his property into money for the purpose of putting it beyond the reach of creditors. The attachmont statutes not only authorize the seizure of the debtor's property for the actunl commission of these acts, they also give the plaintiff the power to attach in order to prevent the intended accomplishment of them.

In Kentucky, in an action on contract, judgment or award, the fact that tho defendant has not property in the state subject to execution sufficient to satisfy the plaintiff's demand is an attachment ground.

62. E.g. CaL. Code Crv. Proc. (Deering, 1931) \& 541; Der. Rev. Star. (1915) §§ 4118, 4122 et seq; D. C. CODD (1929) tit. 24, § 132; IDAHO CoDB ANN. (1932) § 6-509; ILL. REv. STAT. (Smith-Hurd, 1931) c. 11, §§ 21, 31; Ky. CoDe ANN. (Carroll, 1927) Civ. Prac. § 194 et seq; MD. ANN. CodB (Bagby, 1924) art. 9, § 10; Nev. Comp. Laws (Hillyer, 1929) § 8725; N. C. Code (1931) §§ 817, 819; OHIo Gen. Code (Page, 1926) § 11828; TenN. Codz (1932) § 9428; VA. CoDv ANN. (1930) § 6390 et. seq.

In New York and South Carolina there is no garnishment process as such, but debts and credits owing to the principal defendant may be reached under the attachment statutes of those states and held as security for any judgment the plaintiff may recover. NEW YORK C.P.A. \$ 916 et seq; S. C. CODE OF LAWG (1932) § 538 et seq. 
North Dakota, South Dakota and Texas, however, while garnishment is available in any case in which an attachment would issue, creditors, at least, are not thus restricted, although some form of affidavit, or bond, or both may be required of them. ${ }^{63}$ And, of course, formal attachment grounds disappear as prerequisites in all these states when judgment is recovered against the defendant in the main action, and garnishment is sought in aid of execution. of affidavit may be required, ${ }^{65}$ and in Illinois, Nevada, New York and Tennessee execution must have been returned unsatisfied, wholly or in part. ${ }^{66}$ In Kentucky and South Carolina, not only must execution have been returned wholly or partly unsatisfied, but to reach persons indebted to the defendant, the judgment creditor must proceed by way of an equitable action for discovery. ${ }^{67}$ Ordinarily, collection of a judgment through garnishment of wages will necessitate the levying of successive writs to meet each accruing installment, ${ }^{\text {cs }}$ but in New

63. ALA. CoDE (1928) § 8051; ARIz. CoDe (Struckmeyer, 1928) § 4258; ARrE. Dig. Stat. (Crawford \& Moses, 1919) § 4906; FLA. Cosip. LATS (1927) § 5299; GA. CODE ANN. (1926) § 5265 et seq; MinN. STAT. (Supplement, 1931) § 9356; N. MI. STAT. ANN. (Courtright, 1929) § 59-101; N. D. CoMIP. LANTB ANN. (1913) § 7568; S. D. CoMr. LAwS (1929) § 2453 et scq; TEx. REP. Crv. CODE (1928) art. 4076.

The affidavit required in these states takes a variety of forms. In Alabams it is simply to the effect that the process is believed necessary to obtain satisfaction of the claim. In Arizona, New Mexico and Tezas it is to the effect that the defendant has not, to the knowledge of the affiant, property in his possession in the state sufficient to satisfy the claim, and that the garnishment applied for is not sued out to injure either the defendant or the garnishee. In Georgia the affant must have good reason to suppose that his claim, or soms part thereof, will be lost unless the process issue.

64. E.g., ALA. CoDE (1928) § 8051; ARIz. CoDE (Struckmeyer, 1928) § 4258; Ark. Dig. Stat. (Crawford \& Moses, 1919) § 4906; Fun. Cosip. Lunps - (1927) § 5286; GA. Code ANN. (1926) § 5265 ct scq; Mrinn. Stat. (MIason, 1927) § 9356; N. MI. STAT. ANN. (Courtright, 1929) § 59-101 N. C. Code (1931) § 719; N. D. Comir. Latts ANn. (1913) § 7779; Orlo Gen. Code (Page, 1926) § 11772; Complete Tex. Stat. (1928) art. 4076; VA. Code ANN. (1930) § 6509.

65. E.g. Alabama, Florida, Georgia, Minnesota, North Càrolina, North Dakota and Ohio. See supra notes 63 and 64 .

66. Ill. Rev. STAT. (Smith-Hurd, 1931) c. 61, § 1; NEv. Cosip. LuATS (Hillyer, 1929) $\S 8746$; N. Y. C. P. A. § 684; TENN. CoDE (1932) 8946. In Iraryland, any plaintiff having a judgment may, instead of any other execution, issue an attachment against the lands, tenements and credits of the defendant in the plaintiff's own hands or of a third person. MID. ANN. CODE (Bagby, 1924) art. $9, \S 29$.

67. Ky. Code Ann. (Carroll, 1927) Civ. Prac. § 439; S. C. Code of Latrs (1932) § 746 et seq.

68. In the following states garnishment apparently reaches not only wages which are absolutely due and payable to the principal defendant as of the time of service of the process, but also wages which fall due up to the time of the garnishee's answer. ALA. CoDE (1928) § 8055; FLA. Costr. LAws (1927) 
York the writ of garnishment operates as a continuing levy until the judgment is fully satisfied..$^{99}$ And in California the lien endures for three years after issuance. ${ }^{70}$

Wage exemptions in these two groups of states are on the wholo higher than those in the New England states. Wage exemptions of the second group of states as compared with the first group do not appear so much more favorable to debtors as to be significant upon the variations of their wage earner bankruptcy totals, or upon the increasing size of those totals. For convenience of reference they are set forth here in tabular form, corresponding to Tables I and II, supra.

$$
\begin{aligned}
& \text { Alabama } 71 \quad-\$ 25 \text { per month. } \\
& \text { California } 72 \text { - earnings for personal services rendered within }
\end{aligned}
$$

§ 5289; GA. CODE ANN. (1926) §§ 5271, 5272; NEv. CoMp. LAws (Hillyor, 1929) § 8731; N. M. STAT. ANN." (Courtright, 1929) §§ 59-116, 59-118; N. D. CoMP. LuWS ANN. (1913) §§ 7574, 7575; N. C. CoDE (1931) § 819 and Goodwin v. Claytor, 137 N. C. 224, 230-231, 49 S. E. 173 (1904); TENN. Code (1932) $\S \S 9433,9435$. And in Ohio, up to the time of the trial of the main action. OH10 Gan. CoDe (Page, 1926) $\S 11848$. But in. Minnesota, only as of the time of service of the process. MinN. Stat. (Mason, 1927) \& 9361.

69. N. Y. C. P. A. § 684 .

70. CaL. Codn Crv. Proc. (Deering, 1931) § 542 b.

71. ALA. CODE (1928) \& 7887.

72. CaL. Code CIV. Proc. (Deering, 1931) \& 690 (10).

73. GA. Code ANN. (1926) § 5298.

74. ILL. Rev. STAT. (Smith-Hurd, 1931) c. 62, § 14.

75. Kx. Stat. (Carroll, 1930) \& 1697.

76. Supra note 53.

77. MiNn. Stat. (Mason, 1927) § 9447 (16).

78. N. Y. C. P. A. $\S 684$.

79. OHIo GeN. CoDE (Page, 1926) § 11725 (6). 


\begin{tabular}{|c|c|}
\hline Tennessee 80 & $\begin{array}{l}\text { - } 90 \% \text { of vages of } \$ 40 \text { or less per month and } \$ 36 \\
\text { of wages over } \$ 40 \text { to heads of families. }\end{array}$ \\
\hline Virginia 81 & - \$50 per month to heads of families. \\
\hline Arizona 82 & $\begin{array}{l}\text { - } 50 \% \text { of wages for services rendered vithin thirty } \\
\text { days. }\end{array}$ \\
\hline Arkansas 83 & $\begin{array}{l}\text { - wages for sixty days if less than the amount } \\
\text { exempt under the state constitution. }\end{array}$ \\
\hline Delaware 84 & $\begin{array}{l}\text { - } 90 \% \text { of the wages of any person residing in New } \\
\text { Castle county, except where the levy is for board } \\
\text { or lodging and for an amount not exceeding } \$ 50 .\end{array}$ \\
\hline $\begin{array}{l}\text { District of } \\
\text { Columbia } 85\end{array}$ & $\begin{array}{l}\text { - } \$ 100 \text { per month to residents who support families } \\
\text { in the District. }\end{array}$ \\
\hline Florida 86 & - wages of heads of families wholly exempt. \\
\hline Idaho 87 & $\begin{array}{l}\text { - } 75 \% \text { of earnings for the preceding thirty days but } \\
\text { not over } \$ 100 \text { at any one time, and } 50 \% \text { only if the } \\
\text { debt is for necessaries, where such earnings are } \\
\text { necessary to support a resident family. }\end{array}$ \\
\hline Mraryland $87 a$ & $-\$ 100$ due. \\
\hline Nevada 88 & - same as California. \\
\hline \multicolumn{2}{|c|}{ New Hampshire 89 - $\$ 20$ except as to necessaries. } \\
\hline New Mexico 80 & $\begin{array}{l}-80 \% \text { of wages up to } \$ 75 \text { for the preceding thirty } \\
\text { days to heads of families except as to necessaries. }\end{array}$ \\
\hline North Carolina 81 & $\begin{array}{l}\text { - wages for sixty days preceding the levy where } \\
\text { necessary for support of resident family. }\end{array}$ \\
\hline North Dakota 92 & - same as North Carolina. \\
\hline Rhode Island 93 & \$10 except as to necessaries. \\
\hline
\end{tabular}

80. TENN. CODE (1932) § 7711.

81. VA. CODE ANN. (1930) § 6555 .

82. ARIZ. CODE (Struckmejer, 1928) § 1738 (18).

83. ARK. Dig. Stat. (Crawford \& Moses, 1919) § 5546. Personal property to the value of $\$ 200$ is allowed as an exemption to unmarried persons, and to the value of $\$ 500$ to heads of families under the Arkansas Constitution, art. IX, §§ 1, 2.

84. DeL. Rev. Stat. (1915) § 4331.

85. D. C. CODE (1929) tit. 24, § 313.

86. FIA. CoMIP. ILATS (1927) § 5792.

87. IDAFO CODE ANN. (1932) \& 8-204 (7).

87a. MD. ANN. CoDE (Bagby, 1924) art. 9, § 33.

88. Nev. CoMP. Laws (Hillyer, 1929) $\S 8844$ (8).

89. Supra note 53.

90. N. M. Stat. ANn. (Courtright, 1929) § 59-126.

91. N. C. CODE (1931) § 721.

92. N. D. CoMP. LAWS (1913) § 7782 .

93. Supra note 52. 
South Carolina 94 - same as North Carolina.

South Dakota 95

Texas ${ }^{96} \quad$ - current wages wholly exempt.

Wyoming ${ }^{97}-50 \%$ of wages for sixty days preceding the levy where necessary for the support of a residont family.

From this brief summary of the collection remedies of the states in question available against wage and salary earner debtors and wage or salary exemptions, it is not observable that they suggest any Bankruptcy reforms which will reduce the totals or resolve the variations in bankruptcy totals of the different states. Moreover, quite clearly the wage earner bankruptcy totals of one state are more numerous than they are in another state not by reason of the variations in their legal collection remedies and wage exemptions. Thus, the wage earner bankruptcy totals of either Alabama, Ohio, or of Tennessee are not greater than the aggregate of such bankrupts in the total of the New England states because the collection remedies and wage exemptions of Alabama, Ohio, or of Tennessee, are more adverse to the debtor. On the other hand, there is no basis for the conclusion that a state makes a record of few wage earner bankruptcies merely because its collection remedies or exemptions may be more adverse to creditors. Witness, for example, Tennessee and Arizona (Tennessee with 2474 wage earner bankruptcies in 1931, Arizona with 24) with garnishments apparently more readily obtainable and wage exemptions not appreciably larger in Arizona. On the other hand, these conclusions, of course, are without prejudice to a conclusion that, in any or each state, collection procedures have a significant bearing upon its wage and salary earner bankruptcies, whether the totals are large or small.

Before dismissing this discussion of the significance, or rather, lack of significance, of collection remedies and wage exemptions of the several states in pointing the way to needed Bankruptcy reforms, and the lack of correlation of these remedies and wage exemptions with the varying, ever-increasing wage earner bankruptcy totals of the states cited, reference should be made in this connection to assign-

94. S. C. CODE OF LAWS (1932) § 750.

95. There is no wage exemption statute in South Dakota. The dobtor may, if the head of a family, select from his personal property not nbsolutely exempt, goods, chattels, merchandise, money or other personal property, not to oxcoed $\$ 750$ in value; and if a single person, not the head of a family, to tho valuo of $\$ 300$, which shall be exempt. S. D. CoMP. LAWS (1929) § 2659.

96. TEx. REv. Crv. CoDe (1928) art. 4099.

97. WYo. REv. STAT. (1931) § 89-3125. 
ments of future wages and salaries. ${ }^{88}$ While in legal contemplation such assignments are lumped with general dogma relating to assignments of rights, especially contract rights, or are regarded as financing and security media, it seems that frequently they should be regarded as a collection device, and, when they are used other than for purposes in terrorem the debtor, that is, when they are actually served upon the employer, their principal functions become that of collection and of preferring the assignee-creditor in the collection process.

Looking upon such assignments and their availability as collection remedies under the laws of the several states, it is not observable that they point to any needed reforms of the Bankruptcy Act or of its administration. Furthermore, it is quite clear that the variations of wage and salary earner bankruptcy totals in the several states are not to be accounted for by the legal restrictions, if any, which are put upon their use in the several states. Thus, in states with the smaller wage earner bankruptcy totals, as reported supra, Table II, it may be observed that the District of Columbia, Idaho, Nevada, North Dakota, South Carolina and South Dakota, among other states, have no statutory provisions regulating or restricting the use of wage or salary assignments. ${ }^{09}$ On the other hand, among the states having the larger wage earner bankruptcy totals, as reported supra, Table I, Alabama ${ }^{100}$ and California, ${ }^{101}$ and Ohio ${ }^{102}$ in the case of employees of employers required to pay at stated intervals, provide that assignments of future wages are void with certain exceptions as to assignments given to secure the pur-

98. For a comprehensive discussion of the use and validity of vage assignments under the laws of the several states, see the article by Fortas, Wago Assignments in Chicago-State Street Furmiturc Co. v. Armour \& Co. (1933) 42 Y ALE L. J. 526.

99. Among the other states in this group, Arizona, Arliansas, Delaware, Florida, Maryland, North Carolina, Rhode Island, Texas and Wyoming regulate wage assignments only in connection with loans. See ArIz. Code (Struclmeyer, 1928) § 2012; ARK. DIG. STAT. (Crawford \& Mioses, 1919) § 7133; DEr. LuWS (1927) c. 208; FLA. GeN. LaWS (1927) § 4014; MID. ANN. Code (Bagby, 1924) art. 58 a; N. C. CoDe (1931) § 4509; R. I. ACrs (1923) pp. 30-31; TeX. Rev. Crv. Code (1928) art. 6165 a; Wyo. REv. Stat. (1931) §§ 8-101, 8-102. Of these, Arkansas, Maryland and Rhode Island, and, in addition, New Hampshire and New Miexico have statutes regulating wage assignments other than in connection with loans. See ARK. DIG. STaT. (Crawford \& Moses, 1919) § 7134; MD. ANN. CodE (Bagby, 1924) art. 8, § 11; R. I. GEN. Lutws (1923) $\S 4420$ et seq; N. H. PUB. Laws (1926) c. 327, § 3; N. M. Stat. ANN. (Courtright, 1929) \$ 8-101.

100. ALA. CODE (1928) § 9232.

101. CaL. Crv. Code (Deering, 1931) § 955.

102. OHIO GEN. CODE (Page, 1926) § 12946 (1) (2). 
chase price of necessaries. ${ }^{103}$ And in Ohio, such an assignment, up to $25 \%$ of the earner's wages if married and $50 \%$ if not married, may be given to secure a loan, provided that it is in writing signed by the borrower and consented to by his wife. ${ }^{104}$ In Massachusetts, no assignments of unearned wages, other than those made to secure loans of less than $\$ 300$, are valid unless assented to by the employer. ${ }^{105}$ In Minnesota, every assignment of wages to be earned requires the written consent of the employer and of the wife of the employee, and is void if given for wages to be earned more than 60 days after execution. ${ }^{106}$ In the remaining jurisdictions of this group there are special restrictions according to the statutes only where the assignment is taken to secure a loan. Thus, in Illinois future assignments of wages are restricted or regulated only when given under the Small Loans Act; in such cases only $50 \%$ of the wages assigned may be held thereunder. ${ }^{107}$

It may also be observed, if it is important to note, that the legal position of wage assignments after discharge in Bankruptcy of the assigning wage earner varies in the several states. With the exception of Texas, ${ }^{108}$ the only states in the groups here considered where the question has been passed upon are of the first group. Kentucky, ${ }^{100}$ Minnesota ${ }^{110}$ and Ohio ${ }^{111}$ have held that the bankrupt's discharge terminates his outstanding wage assignment. Illinois ${ }^{112}$ and Massa-

103. In Alabama assignments of wages to be earned within 30 days may bo taken for the purchase price of certain enumerated necessities. ALA. CODE (1928) § 9233. Similarly, in California as to necessaries in general, oxcopt that no time limit is prescribed. Supra note 100 . In Ohio, $10 \%$ of such earnings may be assigned to apply on a debt for necessaries. Supra noto 101.

104. Oमlо GEN. CoDe (Supp. 1931) §§ 6346-11, 6346-12. Tho payment of $\$ 300$ or less in money, credit, goods or things in action as consideration for the assignment is deemed a loan on salary or wages within the meaning of the statute which applies only to licensees under Smal Loans Act.

105. Mass. GeN. LaWs (1932) c. 154, §§ 2, 3, 4.

106. MiNN. STAT. (Mason, 1927) §§ 4136-4137. Assignments to socuro loans of less than $\$ 200$ are regulated by $\S 4138$.

107. ILL. REv. STAT. (Smith-Hurd, 1931) c. 74, § 16 . Other provisions relating to assignments in connection with loans follow: GA. CODE ANN. (1926) §§ 3465 and 1770; KY. STAT. (Carroll, 1930) § 4758-a-l et seq; N. Y. Consor. LAWS (Cahill, 1930) c. 3 , § 347 ; c. $42, \S 42$; VA. CoDE ANN. (1930) § 4168 (52) et seq.

108. See Leslie v. Roberts, 32 S. W. (2d) 873 (Tex. Civ. App. 1980).

109. Levi v. Loevenhart, $138 \mathrm{KY} .133,127$ S. W. 748 (1910).

110. Leitch v. No. Pac. Ry. Co., 95 Minn. 35, 103 N. W. 704 (1905).

111. Rowe v. Public Finance Co., 37 Ohio App. 13, 174 N. T. 164 (1930). The same result has been reached in Montana and Nebraska and in the fedoral courts generally. See Fortas, Wage Assignments in Chicago-Stato Stroot Furniture Co. v. Armour \& Co., 42 YALE L. J. 526, notes 76, 77.

112. Monarch Discount Co. v. Chesapeake \& Ohio Ry. Co., 285 Ill. 233, 120 N. E. 743 (1918). 
chusetts ${ }^{113}$ have held the contrary. But this variation cannot be made to account for the variation in bankruptcy totals.

This brief review of assignments of future wages is adequate, it is believed, to support reiteration of the point that the varying restrictions or lack of restrictions upon their use under the laws of the several states do not account for the variations in the wage and salary earner bankruptcy totals of the several states nor for the increasing size of those totals. In a given state they may be used with facility yet its wage and salary earner banlruptcy totals may be low; in another state their use may involve formal prerequisites and other legal restrictions but the wage and salary earner bankruptcy totals of the state may be high.

By way of summary upon the views here advanced respecting the correlation of collection remedies, including assignments of future wages and salaries, with wage and salary. earner bankruptcies, it is concluded: (1) That compelling collection proceedings may well have been a "contributing factor" to the decision of our wage and salary earner bankrupts to file their petition in bankruptcy; (2) that notwithstanding the relation of wage and salary earner bankruptcies to collection remedies, as conceded in point (1), there is no significant correlation between the variations in the collection remedies of the several states and the increases and state to state variations of wage and salary earner bankruptcy totals; (3) that propositions regarding the impact of collection proceedings upon bankruptcy totals stop short of the problems of credit administration implicit in those totals, and, of course, fail to indicate the possible use of collection procedures and the Bankruptcy Act as coöperative instrumentalities of credit control.

\section{The Problems of Credit Management Implicit In Our Wage and Salary Earner Bantruptcies-Necessary Reforms}

From the foregoing discussion it should be clear that the writers' criticisms of proposals to amend the Bankruptcy Act are not based upon fears of what might be accomplished by so doing. Instead, they are based upon convictions that such a program is, for the most part, too remote from the more important credit problems implicit in our wage and salary earner bankruptcies to bring about any substantial improvement.

The particular amendments proposed by the Attorney General, as heretofore briefly reviewed, tell the populace once more that

113. Citizens' Loan Ass'n v. Boston \& Mraine Rr. Co., 196 Miass. 528, 82 N. E. 696 (1907). 
honest and willing debtors will be accorded rights under the Bankruptcy laws of the United States, and that culpable debtors will be run down and punished by the Government. The Government again champions honest and willing debtors and promises to punish. reprehensible debtors. This ideal classification, however, has ever presented its difficulties. Most debtors see themselves in the approved class; most creditors are likely to consider that their defaulting debtors, especially their technically bankrupt debtors, belong to the unapproved class. Moral judgments are required in each case because the classes do not otherwise exist. There is little probability that the officials provided for by the Attorney General's proposed amendments would more effectively surmount these diffculties of classification than have officials of the past in Bankruptcy administration or in other fields of law administration. And, even if there were such probability, the more important problems of credit management implicit in our bankruptcy totals would still remain, namely, (1) the elimination, or at least control, of the sources of our defunct debtors, including technical bankrupts, and (2) the stabilizing of outstanding credit extensions once they have been made.

These problems of credit management implicit in our wage and salary earner bankruptcies neither begin nor end with bankruptcies. The "causes" of these bankruptcies do not arise at Bankruptcy. Our commercial, credit and financial interests should realize that Bankruptcy is neither the time nor the place to seek the stabilization or validation of their receivables, nor to create judgments upon the moralities of debtors.

It is proposed, therefore, in the present section of this article briefly to examine these problems of credit management in their more comprehensive aspects and, in so far as time elements may be suggested, to give more attention to these problems at the origination rather than at the dissolution of credit extensions.

The problems of credit management relating to wage and salary earners are the problems of management of the major part of our consumer credit. Wages and salaries are the principal support for that credit. Business, at production and throughout distribution, looks forward to capturing these earnings. They are an indispensable support of profits, rents and interest. These earnings are not an unlimited fund-at least such has been our experience to date. ${ }^{114}$ As yet, they have not proved capable of unlimited expansion through

114. Of course, this is not intended, by implication even, to indicato the ' writers' resignation to such formulae of politico-economic propoganda regarding wages as the Subsistence Theory of Wages, the Iron Law of Wages or the Wages Fund Theory. 
credit. Indeed, apparently in the case of a great number of their recipients, these earnings are scarcely adequate for the subsistence requirements of the earner and his dependents. ${ }^{110}$

Notwithstanding this elementary learning regarding consumer credit, we have witnessed, especially during the past decade, its irresponsible inflation. Rising wage scales and pressure for new outlets of increased production undoubtedly stimulated the exploitation. This exploitation has been carried on by making credit a sales accessory. "Easy" credit terms have been offered to strike down "sales resistance." "Easy" credit terms have been translated into longer and still longers terms under the general slogan, "Buy Today -Pay Later." 116 Accordingly, the consumer has been taught lightly to regard his credit undertakings-their ethical content being debased by those whose economic interests ever argued the perpetuation of their moral sanctions. Accordingly, consumer credit has become greater in volume and more and more widely diffused. Accordingly, earnings farther and farther in the future-an economically insecure and fragile future for so many earners-have been burdened for purchases and loans.

Promotions to "Own Your Own Home," houses for installment sales, finance companies, credit unions, pawnbrokers and personal small loans companies with their wage earner accommodation paper, chattel mortgages on household effects and wage assignments, have built themselves upon this exploitation of future wages and salaries. Established enterprises, heretofore conservative in their retail prac-

115. See, The Cost of Living in Twelve Industrial Citics, National Industrial Conference Board (1928), PaUl H. Douglas, Wages aNd the FasmuY (1925); Reed, The Ability to Pay for Medical Care, Publication No. 25, Committee on the Cost of Medical Care (1932); Cost of Living in the United States, Bull. No. 357, Bureau of Labor Statistics, U. S. Dept. of Labor (1924); Douglas, Wage Earner Banliruptcies-State vs. Fedcral Control (1933) 42 YALE L. J. 591, 628-638. See also, Sturges, Whither Do We Wander (Jan. 6, 1931) CoNNecticut Safe Deposit Ass'N Quart. Bul.. 7; id. (1931) 20 Safe Deposit BuLL. (N. Y.) No. 6, p. 305.

116. See Noyes, Financing Prosperity on Next Year's Income (1927) 16 Yale ReviEw 227; Lester, A Dollar Down and Ten To Go: Tho Pros and Cons of Installment Credit (1928) 61 SURveY 133; Living and Dying on Installnents (1925) 50 WORLD's WorK 575; Hawthorne Daniel, Living and Dying on Installments (1926) 51 WORLD's WORK 320; Too Mfuch Credit Not Good for tho Worker, LITERaRy Digest, August 1, 1925 at 62; Frederick, Dollar-Dovon Serfdom (1926) 117 IndEPENDENT 299; EvaNS CLARK, FinsNcing THE Consumer (1930) c. II. Cf. Strengthening of Procedure in the Judicial System, supra note 5 , at $85, \mathrm{n} .59$.

Of course, in terms of the dollar-volume of such sales, this exploitation has not reached the lowest brackets of earnings. Personal small loan enterprises have extended farther into this "market." See EvaNs ChARE, op. cit. oupra. 
tices, have been forced to follow the innovations of their more aggressive competitors.

Commercial, credit and financial interests should recognize not only that Bankruptcy laws are neither responsible ${ }^{117}$ for such inflationary exploitation of consumer credit nor a cure for it, but also that to stabilize and validate consumer credit they must put in order their own practices, particularly their own consumer sales and credit practices. Let these interests, therefore, undertake anew to educate themselves to the conservation, rather than to the irresponsible exploitation, of consumer credit. May they come to know again that the sources of consumer payments are not without limit. May they learn anew that the several classes of credit-grantors have a community of interest in their common debtor; that those who sell with security as well as those who sell upon open account are seeking to charge a common source of payment which, at least as yet, has never proved to be unlimited or capable of indefinite expansion. Let these interests learn once more that over-exploited credit-grants are the surest breeders of bankruptcies-technical, or otherwise.

As recognition is again accorded the fact that consumer earnings (and savings when there are any) are not unlimited or capable of indefinite expansion, costs of consumer credit should be scrutinized anew. Let the new consumer credit promotions be predicated upon the ability of the buyer or borrower to earn and pay-not only the nominal price or principal, but also the veiled costs of the credit, such as refinancing or "renewal" charges, "carrying charges" and "interest"- these in addition to costs of operation and maintenance of the thing acquired. In this connection our commercial, credit and financial interests should also re-examine the striking development of the personal small loans business which is sustained by slogans about "humanitarian purposes" and "sound economic principles." 118 More specifically, let them re-examine whether or not constantly accumulating interest charges upon its millions, and probably billions, of dollars of loans to earners generally qualifying to borrow only from $\$ 50$ to $\$ 200,119$ at such rates as $3 \frac{1 / 2}{2} \%$ per month upon unpaid balances, authorized under the Uniform Small Loans Act, are conducive to a stable or healthy consumer market or consumer credit.

Our commercial, credit and financial interests should also recognize once more that exploitation of the consumer market through

117. Suggestions (see op. cit. supra note 5, at 9) that the bankruptcy law "encourages reckless extravagance and facilitates fraud" (italics ours) aro high-sounding and arouse the emotions, but misleading as sign posts to offective methods of reform.

118. See Evans ClaRK, op. cit. supra note 116.

119. Id. at $60-62$. 
sales for cash can have its impact upon savings and earnings of the consumer and can destroy outstanding credit grants soundly extended. Cunning of advertising and pressure in salesmanship for cash sales are not without their costs to stability of the consumer market and consumer credit.

If these observations encourage their own criticism as overemphasizing, by implication at least, the short-comings of the commercial, credit and financial interests here addressed without regard for the short-comings of the consumer, including his extravagance and incompetence respecting family finances, let it be so. The problem is not one of "blame," but rather one of inducing reform by those who have the power of reform-by those who have the power to control our consumer market and credit.120

If and as commercial, credit and financial interests shall undertake thus to discipline themselves in the conservation and stabilization of consumer credit, it is submitted that state legislatures and the Congress can effectively coöperate with them by enacting two comparatively simple pieces of legislation. This legislation, however, should be understood as intended primarily to aid commercial, credit and financial interests in helping themselves to discipline their members in fair and sound practices relating to consumer credit. It can be no cure of its own force. Its effectiveness would depend very directly upon the extent to which these interests should use it for such purposes. It would not serve as an eradicator of bankruptcies. It is conceived as a coöperating agency for credit control.

\section{Proposals To Aid in Coöperative Credit Control}

The two proposals should be considered as an entirety respecting purpose and effect, namely, to repeat, as an aid to credit control. In enumerating them separately and in referring only the second proposal to Congress for incorporation in the Bankruptcy Act, while both are submitted for state enactment, their entirety of purpose should not be obscured.

120. It is thoroughly realized that by identifying these interests as holding the power of consumer stabilization, the complex problems of executing that power are not solved. These problems are neither few nor simple, a realization which is vitalized as the present so-called depression wears on. By the same token, however, it may be reiterated that these problems will not be resolved by the passing of a law-even amending the Bankruptcy Act-or by changing the personnel charged with its administration.

Even with respect to "fraudulent" and culpable borrowers and buyers on credit, these responsibilities of credit management cannot be effectively shifted to bankruptcy or other statutory officials. They cannot be expected substantially to reward creditors for irresponsible volumes of videly difiused credit-grants. See note 20, supra. 
The proposals to aid in enforcing this coöperative conservation of consumer credit are as follows:

I. (a) That state legislation be enacted whereby any creditor (other than a secured creditor suing merely to foreclose or to reclaim upon default) who shall institute an action to collect a money claim, shall share any liens arising by attachment, garnishment or judgment which he may acquire thereby, with any and all other creditors of the defendant, existing at the time, who shall, after notice, and within a prescribed time thereafter, file and prove their claims.

(b) That any assignment of wages or salary shall be treated as prescribed in (a).

II. In coöperation with the foregoing state legislation seeking to enable creditors to enforce regard for the mutuality of interest of creditors in their common debtor with respect to collection proceedings, let the state legislatures, and Congress in the Bankruptcy Act, provide a new order of priorities among general creditors. Let it be enacted that general unsecured creditors (in Bankruptcy those having "provable claims"), and secured claims as respects any deficiency, shall rank according to the date of their respective credit extensions.

It is believed that the state legislation involved in Proposal $I$ is consistent with and in furtherance of existing commercial policies which have already been promoted by some wholesale trade organizations with respect to their retail dealers. These wholesalers have recognized their common interest in retailers who maintain business relations with two or more of them. Thus, the by-laws of the New Haven Branch of the Wholesale Grocers Association provide as follows: "Paragraph II, The Object: The object of this organization shall be to protect and promote the financial interests of its members by preventing failure when possible and by coöperating in bankruptcy cases in which its members are concerned, and it is understood and agreed that in case attachment or other proceedings are necessary locally for the protection of the assets of any debtor, such action shall be taken through the attorney of this organization for the benefit and in the interest of all members of the organization." (Italics ours).

As wholesalers find a community of interest in their retail outlets, retailers, together with other commercial and credit interests, may likewise organize and recognize a community of interest in a consumer debtor. But trade organizations may have their limitations in enforcing this mutuality of creditor-interest by the fact that their by-laws do not function against non-members and by 
reason of the fact that a single person may well become debtor to the members of more than one organization.

Proposal I should aid in meeting these limitations and in enforcing among creditors more comprehensive application of the principle of interdependence.

Assignments of future wages and salaries should be regarded as a collection device of like import as attachment or garnishment for purposes of the "underfiling" (that is, proving of claims under the original process) and proration here proposed. Depending upon their continuation, they may be even more anti-social to the common interests of all other creditors than garnishment.

Such assignments may be made effective for purposes of underfiling and sharing by a provision that, upon service of such an assignment upon an employer, such employer shall certify as to the employment of the assignor and return the assignment to a designated court. The court, or clerk thereof should thereupon, for purposes of underfiling and proration proceedings, proceed as upon the return of an attachment or garnishment or the procurement of a judgment. In the meantime accruing wages should be paid in full by the employer to the court to which the assignment was properly returned.

The community-of-creditor-interest here sought to be enforced is that resulting from the elimination of preferences gained by legal proceedings or assignment whereby one credit-grantor, in utter disregard of the outstanding credit of other credit-grantors, can scalp the common, and, all too frequently, sole source of payment of the debtor's several obligations. Such a reward for "diligence" in collection is too high a price to be imposed upon the others. Such a reward unnecessarily tolerates speculative and irresponsible credit-grants.

It may be conceded that some lawyers will oppose such a socialization of collection processes. ${ }^{121}$ The game of preference-scalping through collection proceedings and assignment is thereby taken away. Others, probably, would be more tolerant of the proposal.122

121. That a similar policy obtains in some states under statutes granting receiverships of corporations for designated causes, see Parten v. Southern Colonization Co., 146 Minn. 287, 178 N. W. 744 (1920); Clark, Reccivers at the Instance of Judgment Creditors and Priorities Incident Thereto (1930) 17 VA. L. REv. 54 et seq.

122. An analogous legal philosophy and morality may be observed in the fiduciary relationship which courts have enjoined upon creditors who become parties to a composition agreement with their debtor. See Hanover National Bank v. Blake, 142 N. Y. 404, 37 N. E. 519 (1894); Kullman v. Greenebaum, 92 Cal 403, 28 Pac. 674 (1891); Klaw v. Famous Players-Lasky Corporation, 
It remains to point out that some jurisdictions already provide for proration under attachments and garnishments. ${ }^{123}$ The Indiana statute may be quoted for illustrative purposes. Pertinent sections are as follows:

"1014. Any creditor of the defendant, upon filing his affidavit and written undertaking, as hereinbefore required of the attaching creditor, may, at

207 App. Div. 211, 201 N. Y. Supp. 691 (1st Dep't 1923); In re Chaplin, 115 Fed. 162 (D. Mass. 1902).

123. CoLo. Comp. Laws (1921) §§ 99-101; IDAHo CODE ANN. (1932) §\$6-501 -6-503; IND. ANN. STAT. (Burns, 1926) \$\$ 1014-1015, 1010-1020; PA. STAT. ANN. (Purdon, 1930) tit. 12, \& 2747 (domestic attachments).

An minois statute provides that "all judgments in attachments against the same defendant, returnable at the same term, and all judgments in suits by summons, capias or attachment against such defendant, recovered at that term or at the term when the judgment shall be recovered is rendered, shall share pro rata - . - - in the proceeds of the property attached, either in the hands of a garnishee or otherwise," with a proviso, however, that when the proporty is attached while the defendant is removing the same or after it has been removed from the county and is overtaken and returned, or while it is secroted by the defendant or put out of his hands for the purpose of defrauding his creditors, the court may allow the creditor or creditors through whoso diligonce it was secured a priority. ILL. Rev. Stat. (Smith-Hurd, 1031) c. 11, § 37. Provision is also made in the statutes of Delaware and New Jorsey for other creditors to apply under an attachment, and for the appointment of "auditors" to ascertain their claims and distribute the proceeds. DEr. REv. STAT. (1915) §§ 4132-4133; N. J. Comp. LAWS (1910) § 6, p. 136, ot $8 € q ; i d$. (Supp. 1924) $\S 21$, p. 101 . In Delaware, creditors attaching and prosecuting the same to judgment are allowed a double share, or dividend, upon distribution, if such shall not exceed their debt; and in New Jersey, tho plaintiff in the original attachment receives payment of his claim in full first, the residuo, if any, being prorated among the other creditors whose debts have beon allowed. Under the New Jersey procedure the "auditor" has broad powers as to tho discovery of the defendant's property; he may issue warrants for the seizure of money, goods, papers, etc., of the defendant and may sue for debts owing to the defendant. Similar powers are given to 'trustees' in Pennsylvania. PA. STAT. ANN. (Purdon, 1930) tit. 12, § 2791 et seq.

Formerly, in Florida, $\S 9$ of the act of Feb. 1833 (Drg. Fra. LAws (18221881) c. $7, \S 18$ ) which provided, inter alia, that "the judgment in a suit commenced by attachment, shall be satisfied in the same manner as othor judgments obtained in the same term of the Court are, or shall bo, satisfied, out of the lands and tenements, goods and chattels generally of the defondant in attachment," was held to place "judgments obtained at the samo torm, whether the suits in which they were obtained were instituted by attachmont or ordinary summons, upon the same footing," that is, such judgmonts should be satisfied pro rata. Post v. Carpenter, 3 Fla. 1, 3 (1850); Smith v. Bowdon, 23 Fla. 150 (1887). The statute now in force, however, provides that "levies upon the same property under successive attachments shall have precedonco as liens in the order in which they are made." FLA. CoMp. LAws (1027) § 5269.

A similar procedure obtains in France. See Code de Procedure Crving, arto. 656-672 (Petits Codes Carpentier, 1929); CoDe du Travais, arts. 70-70 c, as amended by Law of July 27, 1921 (Petite Collection Dalloz, 1931). 
any time before the final judgment in the suit, make himself a party to the action, file his complaint, and prove his claim or demand against the defendant; and may have any person summoned as garnishee, or held to bail, who had not before been summoned or held to bail; and propound interrogatories to the garnishee, and enforce answers thereto, in lilie manner as the creditor who is plaintiff."

"1015. A dismissal of his action or proceedings in attachment by the first attaching creditor shall not operate as a dismissal of the action or proceedings of any subsequent attaching creditor."

"1018. If judgment in the action be rendered for the plaintiff, or one or more of several plaintiffs, and sufficient proof be made of the goods, chattels, rights, credits, moneys and effects in possession of the garnishee, the court shall also give judgment in favor of the plaintiff as creditors against the garnishee or the property of the defendant, or both, as the case may require; which may be enforced by execution."

"1019. After judgment for the plaintiff, or one or more of several plaintiffs, property attached and remaining unsold may be sold on execution, as in other cases."

"1020. The money realized from the attachment and the garnishees shall, under the direction of the court, after paying all costs and expenses, be paid to the general creditors in proportion to the amount of their several claims as adjusted, and the surplus, if any, shall be paid to the defendant."

Other statutes are more exacting, and properly so it would seem, in requiring notice of the attachment for the benefit of other creditors who may wish to underfile. Thus, the Idaho statute requires that "two days after issuing such writ of attachment [of the original attaching creditor] and delivering it to the proper officer, the clerk must post at the front door of the court house and cause to be published in some newspaper published in the county, ... a notice, setting out the title of the cause and the fact that an attachment has been issued against the property of the defendant. Such notice shall be kept posted at least ten days and shall be published, if in a weekly paper in three issues thereof, and if any other than a weekly paper, in at least six issues."

Under these statutes, any creditor, as well as the debtor, may contest the claim of any other creditor. ${ }^{123}$ Even the claim of the original attaching creditor may be challenged and eliminated without destroying the attachment and proceedings thereunder as respects the underfiling creditors. Thus, it has been held that pay-

124. The U. S. Express Co. v. Lucas, 36 Ind. 361 (1871); Lytle v. Iytle, 37 Ind. 281 (1871); Rouse v. Wallace, 10 Colo. App. 93 (1897). See also, Schmidt v. Colley, 29 Ind. 120 (1867); Compton v. Crone, 58 Ind. 106 (1877). 
ment in full of the attaching creditor's claim does not dissolve the attachment as against the underfiling creditors. ${ }^{125}$

Creditors entitled to prorate under an attachment share in the lien from the date of the original attachment.120 Total claims allowed are fixed for payment in the order for the execution sale.12r No discharge of unproved claims or of unpaid balances is provided in the statute. Any sum realized upon the execution sale in excess of claims proved and allowed in the order of sale is returned to the defendant.

The Supreme Court of Indiana has observed upon the general purpose of its statute as follows: "It is the purpose of our statute" to secure a distribution of the debtor's property among all the attaching creditors, and not to permit it to be absorbed by the claim. of the creditor who sues out the first writ." 128

In sustaining the constitutionality of the Idaho statute, the Supreme Court of Idaho remarked as follows:

"In support of the argument touching the constitutional question, it is insisted that an attachment lien gives a creditor a vested right in the property, . . . and that, therefore, since the statute provides no notice or proceeding against the first attaching creditor, the prorating provision deprives the latter of his property without due process of law and deprives him of the equal protection of the law. If counsel's first position were entirely correct, his latter contention might present a debatable point, but it should be remembered in this connection that the lien of an attachment proceeding such as we have under the Code was unknown at common. law, and that being entirely statutory it is within the province of the legislature to place any restrictions upon the extent of the right of an attaching creditor which it deems advisable. ..

"Under attachment statutes containing a prorating provision, tho attaching creditor does not get an unqualified vested lien, but the lien that he does take by virtue of his attachment is taken subject to the provision. that under certain circumstances other creditors who proceed to judgment and come within the terms of the statute will be entitled to share in the proceeds of the attached property, pro rata. The prorating provision does. not deprive the attaching creditor of a vested right and we, therefore,

125. Stone v. Jones 4 Harr. 255. (Del. 1843); Zeigenhager v. Doe on tho Demise of Strong, 1 Ind. (Carter) 296 (1848) ; Ryan v. Burkam, 42 Ind. 507 (1873) ; Cummins v. Blair, 18 N. J. L. 151 (1840). See also, Taylor v. Elliott 51 Ind. 375 (1875). Cf. Trentman v. Wiley, 85 Ind. 33 (1882).

126. Shirk v. Wilson, 13 Ind. 129 (1859). And consult Plunkett v. Moore, 4 Harr. 379 (Del. 1843).

127. Consult Henderson v. Bliss, 8 Ind. 100 (1856); Cooper v. Metzger, 74 Ind. 544 (1881) ; Lex. R. R. Co.,v. Ford Plate Glass Co., 84 Ind. 516 (1882); E. I. DuPont v. Pennsylvania \& Indiana Coal Co., 69 Ind. App. 320, 121 N. D. 680 (1919).

128. Lex. R. R. Co. v. Ford Plate Glass Co., supra note 127, at 510. 
hold that the constitutional provisions securing due process of lav and equal protection of the law are not involved." 120

It was also held in the same case that the proration statute was not suspended by the Bankruptcy Act as being a state insolvency or bankruptcy law.

It may be, noted that the procedure for underfiling and sharing, which is here proposed, involves no special oppression of the debtor. ${ }^{130}$ Indeed it should tend to his advantage with respect to costs. Pertinent to this point, the Supreme Court of Idaho may be quoted: "Under the prorating statute it is unnecessary for any of the subsequent creditors to attach, the theory being that the first attachment holds the property for the benefit of all creditors . . . and they are relieved from the responsibility, and the debtor from the costs, of the prosecution or suing out of additional attachment process." 131 The Supreme Court of Indiana has made similar observations in this connection. ${ }^{132}$

By way of general summary upon Proposal I: It is believed that the procedure for underfiling and sharing here recommended would aid creditors of a common debtor in enforcing against each other their mutual and common interest in their debtor and his sources of payment. This socialization of collection remedies, including wage and salary assignments, should worli as a resitaining influence upon sellers and lenders in promoting credit sales or loans. They should then realize that under such collection proceedings as are here recommended they may not sell or lend in disregard of outstanding commitments of the debtor and scalp full collection by claiming as the "reward of diligence" the priority which an earlier attachment, garnishment, assignment or even a judgment now gives in most jurisdictions.

This first proposal will be aided to these ends by the coöperation of the second proposal. The second proposal, namely, that priorities shall be given in collection proceedings and in Bankruptcy to general

129. Greene v. Rice, 32 Idaho 504, 509, 186 Pac. 249, 250 (1919).

130. Only claims maturing on or before the expiration of the time for underfiling may be proved in these proceedings. See Ziegenhager v. Doe on the Demise of Strong, supra note 125 . Fixed money clnims, absolutely owing and readily discountable, should, however, be provable. See PA. STAT. ANN. (Purdon, 1930) tit. 12, $\$ 2835$; CoLo. Cosip. LaWs (1921) $\S 105$.

131. Greene v. Rice, 32 Idaho 504, 511, 186 Pac. 249, 251 (1919). See also, Kimball v. Raymond, 9 Idaho 176, 72 Pac. 957 (1903).

An underfiling creditor should not be required to serve separate summons upon the debtor any more than upon the other creditors. Schmidt v. Colley, supra note 124. Consult also E. I. DuPont Co. v. Pennsylvanin \& Indiana Coal Co., 48 Ind. App. 538, 96 N. E. 204 (1911). But cf. Trinidad Bank $\nabla$. Jamieson Co., 60 Colo. 356, 153 Pac. 441 (1915).

132. See Ziegenhager v. Doe on the Demise of Strong, supra note 125. 
unsecured creditors according to the order in which they granted credit to a common debtor is recommended as a further aid to commercial, credit and financial interests in enforcing their community of interest among credit-grantors in a common debtor. This new order of priorities should, in connection with Proposal I, warn each potential credit-grantor against disregarding existing obligations and surcharging the debtor with additional burdens of debt. All too frequently, stable retail credit obligations, predicated upon conservative credit extensions, are brought to default or bankruptcy because a subsequent credit-grantor indulges first in high pressure salesmanship whereby the debtor is over-sold and then in ruthless collection methods. The matter has been modestly expressed as follows: "The creditors themselves are not infrequently to blame for the losses incurred. Credit is often - extended carelessly and without adequate inquiry, or with the expectation that profits from the increased volume of sales will exceed probable credit losses. The consequences of modern salesmanship striving to expand sales regardless of credit risk by encouraging persons of moderate means to make purchases on credit which they can ill afford are undoubtedly reflected in the deplorable statistics of bankruptcy. Unfortunately the losses resulting from such methods do not fall exclusively upon those who are at fault but must be shared by the creditors equally.

"The situation is well illustrated in the case of wage earners who, in large numbers, seek discharge from their debts in bankruptcy because they have been induced by one group of creditors at the expense of another to buy luxuries which they cannot afford. These debtors either because of the more active collection methods of dealers in luxuries or in order to retain property sold to them under conditional sales contracts, often satisfy their debts ouing for luxuries and seek discharge in bankruptcy from debts owing to the butcher, the baker, the grocer and the doctor, who had no part in bringing about their insolvency." 133

It is submitted that an ordering of priorities as here recommended, in connection with provisions for underfiling and sharing involved in Proposal I, would materially aid in protecting "the butcher, the baker, the grocer and the doctor, who had no part in bringing about" the consumer's insolvency and default.

By way of summary:

(1) Our ever increasing number of wage and salary earner bankruptcies are, in terms of reforms, most significant of needs for reform in the management of consumer credit.

133. Op. cit. supra note 5, at 8-9 (italics supplied). 
(2) That reforms of Bankruptcy laws and their administration promise little relief and less cure.

(3) That the management of consumer credit and its reforms are for the most part problems of internal discipline of and by commercial, credit and financial interests.

(4) That only to a very limited extent can legislation enforce upon commercial, credit and financial interests the desired conservation of consumer credit.

(5) In coöperation with such interests, it is submitted that state legislation and the proposed amendment of the Bankruptcy Act can aid these ends by socializing collection proceedings and imposing upon credit grantors who disregard the community of interest of creditors in a common debtor such a penalty as may inhere in such socialization and the priorities which are here recommended.

(6) That such recommendations are not conceived as an eradicator of consumer bankrupts; and they do not imply that bankruptcy reforms are not desirable to the end that creditors' losses from debtors' estates which doubtlessly are inevitable under the best credit management may be reduced. 